\title{
Current Status and Potential Applications of Underexplored Prokaryotes
}

\author{
Kian Mau Goh ${ }^{1, *,+} \mathbb{0}$, Saleha Shahar ${ }^{1}$, Kok-Gan Chan ${ }^{2,3}{ }^{-0}$, Chun Shiong Chong ${ }^{1}$, \\ Syazwani Itri Amran ${ }^{1}$, Mohd Helmi Sani ${ }^{1}$, Iffah Izzati Zakaria ${ }^{4}$ and \\ Ummirul Mukminin Kahar $4, *,+$ (iD \\ 1 Faculty of Science, Universiti Teknologi Malaysia, Skudai 81310, Johor, Malaysia; salehas@utm.my (S.S.); \\ cschong@utm.my (C.S.C.); syazwaniitri@utm.my (S.I.A.); helmisani@utm.my (M.H.S.) \\ 2 Division of Genetics and Molecular Biology, Institute of Biological Science, Faculty of Science, University of \\ Malaya, Kuala Lumpur 50603, Malaysia; kokgan@um.edu.my \\ 3 International Genome Centre, Jiangsu University, ZhenJiang 212013, China \\ 4 Malaysia Genome Institute, National Institutes of Biotechnology Malaysia, Jalan Bangi, \\ Kajang 43000, Selangor, Malaysia; iffahizzati@nibm.my \\ * Correspondence: gohkianmau@utm.my (K.M.G.); ummirul@nibm.my (U.M.K.) \\ + These authors contributed equally to this work.
}

Received: 13 August 2019; Accepted: 8 October 2019; Published: 18 October 2019

\begin{abstract}
Thousands of prokaryotic genera have been published, but methodological bias in the study of prokaryotes is noted. Prokaryotes that are relatively easy to isolate have been well-studied from multiple aspects. Massive quantities of experimental findings and knowledge generated from the well-known prokaryotic strains are inundating scientific publications. However, researchers may neglect or pay little attention to the uncommon prokaryotes and hard-to-cultivate microorganisms. In this review, we provide a systematic update on the discovery of underexplored culturable and unculturable prokaryotes and discuss the insights accumulated from various research efforts. Examining these neglected prokaryotes may elucidate their novelties and functions and pave the way for their industrial applications. In addition, we hope that this review will prompt the scientific community to reconsider these untapped pragmatic resources.
\end{abstract}

Keywords: ex situ diffusion bioreactor; ichip; metagenome-assembled genome; rare microorganisms; shotgun metagenome sequencing; unculturable bacteria

\section{Introduction}

Ample numbers of prokaryote (bacteria and archaea) phyla have been described. The modern classification of prokaryotes involves polyphasic characterizations [1]. The state-of-the-art methods-for instance, phylogenomics, average nucleotide identity, and percentage of conserved proteins-are becoming popular for assisting the delineation of prokaryote genera [2-4]. To date (September 2019), more than 3800 prokaryotic genera have been published directly in the International Journal of Systematic and Evolutionary Microbiology (IJSEM) or were included in the validation list, under the Rules of the International Code of Nomenclature of Bacteria [5,6]. The LPSN database (List of Prokaryotic names with Standing in Nomenclature database; http://www.bacterio.net) archives all validly published names of prokaryotes. The BacDive bacterial metadatabase has collected data on more than 80,500 strains, including 13,500 type strains from 34 bacterial and three archaeal phyla [7]. The World Data Centre for Microorganisms (WFCC-MIRCEN; http://www.wdcm.org) is another data center for microbial resources. The WFCC Global Catalogue of Microorganisms (GCM) has catalogued 447,444 strains from 48 countries and regions. 
The NCBI taxonomy and Silva databases possess the highest numbers of deposited 16S rRNA sequences for the bacterial phyla Proteobacteria, Firmicutes, Actinobacteria, and Bacteroidetes (Table 1). Additionally, these phyla have abundant culture representatives (Figure 1) [7,8]. The primary genera listed in Table 2 have been mentioned in $>868,000$ related articles in the Scopus database. In addition, the top ten strains with the most relevant patents are listed in Table 3.

Currently, there are three main strategies for genome sequencing. The first approach is whole-genome sequencing (WGS) of cultured prokaryotes using Illumina, PacBio, Nanopore, Qiagen, BGISEQ, IonTorrent, or other sequencers. Some of these platforms are more frequently used than others. There are at least 180,312 registered WGS sequencing projects and 250,398 analysis projects in the Genomes OnLine Database (GOLD) of the Joint Genome Institute (JGI) (September 2019) [9]. Proteobacteria (51\%), Firmicutes (29.8\%), and Actinobacteria (12.1\%) account for $92.9 \%$ of the sequenced bacterial phyla. For archaeal phyla, intensive sequencing has been performed for Euryarchaeota $(59.5 \%)$, Crenarchaeota $(24.1 \%)$, and Thaumarchaeota (13.5\%). However, in comparison to that given to the major phyla mentioned above, relatively little attention has been given to other phyla (Table 1, Figure 1). Due to the increasing amount of genomic data, and in order to maintain a certain quality of genome description, the Genomic Standards Consortium (GSC; http://gensc.org) has proposed minimum standards, namely the Minimum Information about a Genome Sequence (MIGS) [10]. Readers can refer to the latest standard guidelines on the official webpage of EMBL-EBI (https://www.ebi.ac.uk/ena/submit/mixs-checklists). Readers are referred to review articles that summarize achievements in the genome sequencing of culturable bacteria [11-13], and to specific reviews on thermophiles [14,15] or bioinformatics tools for microbial genomes [16].

The second primary strategy to genome sequencing is shotgun metagenome sequencing, which can generate DNA reads directly from an environment without the need to culture individual colonies. The whole process involves environmental DNA (eDNA) extraction, amplification, and sequencing by a high-throughput sequencing system. The generated DNA reads can be imagined as mixed-up pieces from different boxes of jigsaw puzzles. In this analogy, each box represents one bacterium or archaeon. DNA fragments generated by the sequencer are grouped (binned) accordingly and assembled into contigs using bioinformatics simulations. The qualified and approved bins are known as metagenome-assembled genomes (MAGs) [17,18]. At the time of writing this manuscript (September 2019), the JGI GOLD has recorded 11,723 MAG projects. The general standard or guidelines for this approach are available in the Minimum Information about a Metagenome-Assembled Genome (MIMAG) [19].

The third main strategy to genome sequencing is single-cell DNA genome sequencing (SAG), which is another culture-independent approach. In comparison to WGS and MAG data, a lower amount of SAG data is deposited in the JGI GOLD (2168 projects). SAG involves disengaging single cells using a microfluidic system or similar, extracting DNA, performing DNA amplification using Multiple Displacement Amplification technology, constructing sequencing libraries, DNA sequencing, and assembling the reads into contigs. Examples of SAG-related articles are provided in [20,21]. Researchers are required to comply with most, if not all requirements of Minimum Information about a Single Amplified Genome (MISAG) before submitting SAG sequences to databases [19]. The JGI earlier funded a project to develop a microfluidic-based mini-metagenomic method [22], an approach that integrates SAG and MAG (Figure 2). Using the new method, the research team successfully extracted and assembled new genomes from hot spring water samples [18,22,23]. Nevertheless, SAG applications have been mostly focused on clinical specimens in oncology, immunology, neurobiology, and prenatal diagnosis. Therefore, SAG is not covered in detail in this article but has been explained in earlier publications [18,24-26]. 


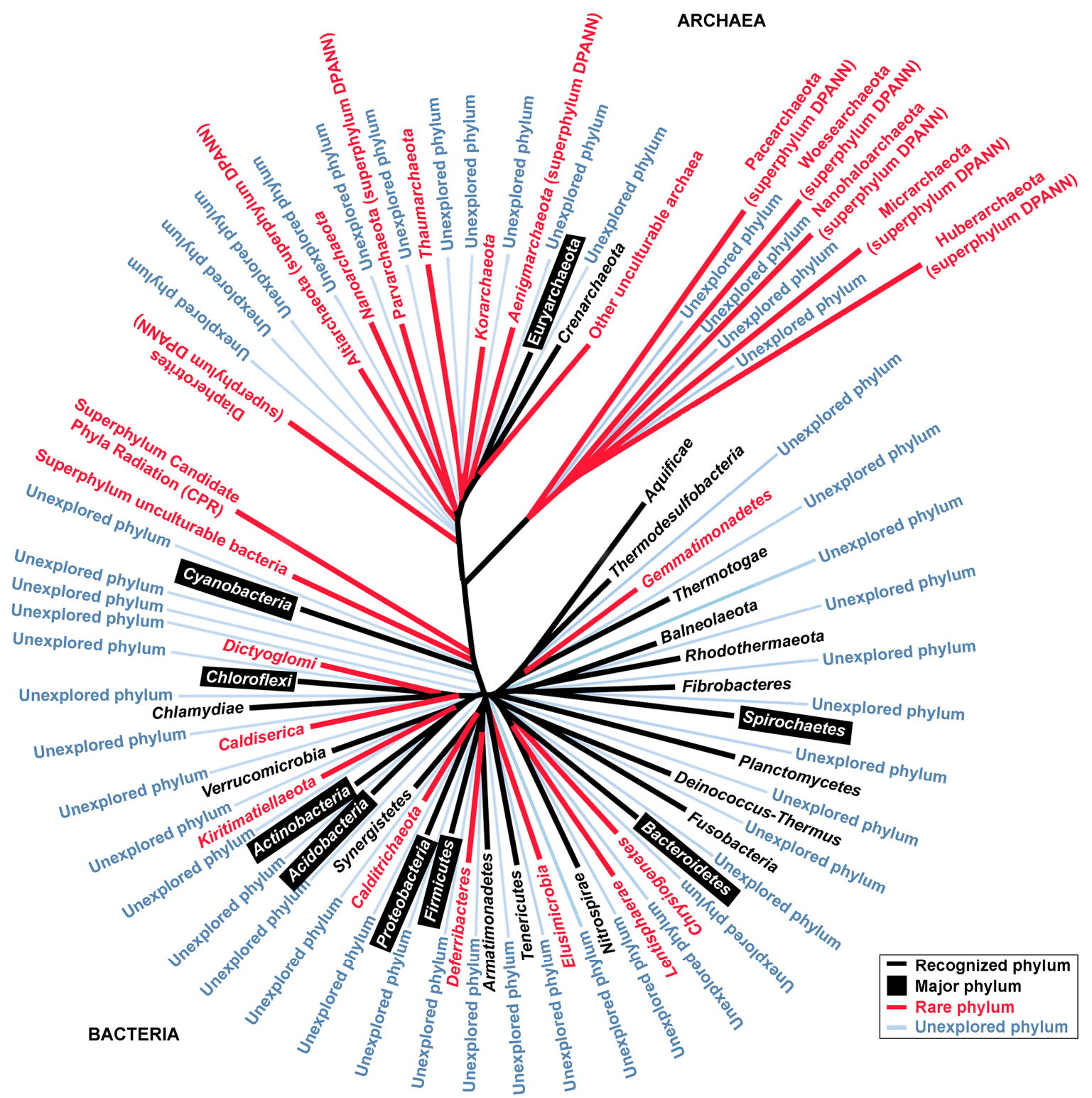

Figure 1. Illustration of $16 \mathrm{~S}$ rRNA phylogenetic tree (phyla). The representatives were aligned using ClustalW, and a maximum-likelihood tree with a bootstrap value of 1000 replicates was built within the MEGA6 package [27]. The transformed radiation tree was redrawn using the FigTree version 1.4.4 program. The number of $16 \mathrm{~S}$ rRNA sequences for each phylum is provided in Table 1.

In this review, we focus our discussion on the current status and potential applications of underexplored prokaryotes. Herein, we define underexplored prokaryotes as (i) unculturable prokaryotes, and (ii) genera consisting of limited species listed in the LPSN database. 
Table 1. Number of $16 \mathrm{~S}$ rRNA sequences related to prokaryotic phyla. Data were obtained from the NCBI Taxonomy and Silva databases [8].

\begin{tabular}{|c|c|c|c|}
\hline \multirow{2}{*}{$\begin{array}{c}\text { Phyla and Candidate } \\
\text { Phyla }\end{array}$} & \multicolumn{2}{|c|}{ No. of 16S rRNA Sequences } & \multirow[b]{2}{*}{ Remarks } \\
\hline & $\begin{array}{l}\text { NCBI Taxonomy } \\
\text { Database }\end{array}$ & $\begin{array}{c}\text { Silva } \\
\text { Database }\end{array}$ & \\
\hline \multicolumn{4}{|c|}{ Domain bacteria } \\
\hline \multicolumn{4}{|c|}{ Recognized bacterial phylum } \\
\hline Acidobacteria & 162,567 & 14,534 & Major phylum \\
\hline Actinobacteria & $4,719,261$ & 60,510 & Major phylum \\
\hline Aquificae & 23,441 & 346 & \\
\hline Armatimonadetes & 16,593 & 752 & \\
\hline Bacteroidetes & $1,116,583$ & 55,663 & Major phylum \\
\hline Balneolaeota & 1589 & $\mathrm{n} / \mathrm{a}$ & \\
\hline Caldiserica & 3630 & 95 & Underexplored culturable, 1 genus, 1 type strain \\
\hline Calditrichaeota & 11,735 & 275 & Underexplored culturable, 1 genus, 1 type strain \\
\hline Chlamydiae & 147,839 & 450 & \\
\hline Chlorobi & 6655 & $\mathrm{n} / \mathrm{a}$ & \\
\hline Chloroflexi & 168,644 & 9245 & Major phylum \\
\hline Chrysiogenetes & 1253 & 12 & Underexplored culturable, 3 genera, 4 type strains \\
\hline Cyanobacteria & 481,641 & 13,906 & Major phylum \\
\hline Deferribacteres & 1968 & 134 & \\
\hline Deinococcus-Thermus & 57,234 & 948 & \\
\hline Dictyoglomi & 296 & 11 & Underexplored culturable, 1 genus, 2 type strains \\
\hline Elusimicrobia & 15,992 & 435 & Underexplored culturable, 2 genus, 2 type strains \\
\hline Fibrobacteres & 8597 & 751 & \\
\hline Firmicutes & $10,435,846$ & 149,757 & Major phylum \\
\hline Fusobacteria & 57,398 & 2216 & \\
\hline Gemmatimonadetes & 34,287 & 21,185 & Underexplored culturable, 1 genus, 2 type strains \\
\hline Kiritimatiellaeota & 1149 & 975 & Underexplored culturable, 1 genus, 1 type strain \\
\hline Lentisphaerae & 8098 & 469 & Underexplored culturable, 3 genera, 5 type strain \\
\hline Nitrospirae & 48,424 & 1297 & \\
\hline Planctomycetes & 110,685 & 9014 & Major phylum \\
\hline Proteobacteria & $28,570,321$ & 238,949 & \\
\hline Rhodothermaeota & 731 & $\mathrm{n} / \mathrm{a}$ & \\
\hline Spirochaetes & 373,114 & 4253 & Major phylum \\
\hline Synergistetes & 22,879 & 1152 & \\
\hline Tenericutes & 80,247 & 2561 & \\
\hline Thermodesulfobacteria & 4586 & $\mathrm{n} / \mathrm{a}$ & \\
\hline Thermotogae & 22,371 & 303 & \\
\hline Verrucomicrobia & 131,082 & 4419 & \\
\hline \multicolumn{4}{|c|}{$\begin{array}{c}\text { Domain bacteria } \\
\text { Superphylum unculturable bacteria }\end{array}$} \\
\hline Abditibacterium & 120 & 155 & $\begin{array}{c}\text { Abditibacterium utsteinense is the first representative } \\
\text { of candidate phylum FBP [28] }\end{array}$ \\
\hline Abyssubacteria & 291 & $\mathrm{n} / \mathrm{a}$ & Bacteria candidate \\
\hline Acetothermia & 3411 & 165 & Bacteria candidate phylum \\
\hline Aegiribacteria & 36 & 52 & Bacteria candidate \\
\hline Aerophobetes & 4393 & 66 & Bacteria candidate phylum \\
\hline Atribacteria & 9087 & 578 & Bacteria candidate phylum \\
\hline Aureabacteria & 106 & $\mathrm{n} / \mathrm{a}$ & Bacteria candidate \\
\hline Calescamantes & 1004 & 12 & Bacteria candidate \\
\hline Cloacimonetes & 10,048 & 301 & Bacteria candidate \\
\hline Coprothermobacteraeota & 811 & 76 & Bacteria candidate \\
\hline Dadabacteria & 3979 & 169 & Bacteria candidate phylum \\
\hline Dependentiae & 1756 & 580 & Candidate bacteria phylum \\
\hline Desantisbacteria & 2580 & 2 & Bacteria candidate phylum \\
\hline Edwardsbacteria & 133 & 4 & Bacteria candidate phylum \\
\hline Entotheonellaeota & $\mathrm{n} / \mathrm{a}$ & 168 & Bacteria candidate \\
\hline Epsilonbacteraeota & $\mathrm{n} / \mathrm{a}$ & 5422 & The class was proposed as phylum [29] \\
\hline Fermentibacteria & 1426 & $\mathrm{n} / \mathrm{a}$ & Bacteria candidate \\
\hline
\end{tabular}


Table 1. Cont.

\begin{tabular}{|c|c|c|c|}
\hline \multirow{2}{*}{$\begin{array}{l}\text { Phyla and Candidate } \\
\text { Phyla }\end{array}$} & \multicolumn{2}{|c|}{ No. of 16S rRNA Sequences } & \multirow[b]{2}{*}{ Remarks } \\
\hline & $\begin{array}{l}\text { NCBI Taxonomy } \\
\text { Database }\end{array}$ & $\begin{array}{c}\text { Silva } \\
\text { Database }\end{array}$ & \\
\hline Fervidibacteria & 698 & 4 & Bacteria candidate phylum \\
\hline Firestonebacteria & 770 & 3 & Bacteria candidate \\
\hline Halanaerobiaeota & $\mathrm{n} / \mathrm{a}$ & 270 & Bacteria candidate \\
\hline Hydrogenedentes & 1984 & 271 & Bacteria candidate \\
\hline Hydrothermae & 1987 & 38 & Bacteria candidate phylum \\
\hline Kryptonia & 4416 & $\mathrm{n} / \mathrm{a}$ & Bacteria candidate \\
\hline Latescribacteria & 6535 & 497 & Bacteria candidate \\
\hline Lindowbacteria & 194 & 1 & Bacteria candidate phylum \\
\hline Margulisbacteria & 1455 & 86 & Bacteria candidate \\
\hline Marinimicrobia & 13,480 & 554 & Bacteria candidate \\
\hline Modulibacteria & $\mathrm{n} / \mathrm{a}$ & 255 & Bacteria candidate phylum \\
\hline Nitrospinae & 24,196 & 2167 & Bacteria candidate phylum \\
\hline Omnitrophicaeota & 15,814 & 507 & Bacteria candidate \\
\hline Patescribacteria & $\mathrm{n} / \mathrm{a}$ & 4521 & Bacteria candidate phylum \\
\hline Poribacteria & 3664 & 49 & Bacteria candidate phylum \\
\hline Rokubacteria & 33,383 & 380 & Bacteria candidate phylum \\
\hline Schekmanbacteria & 1628 & 40 & Bacteria candidate phylum \\
\hline Tectomicrobia & 17,004 & $\mathrm{n} / \mathrm{a}$ & Bacteria candidate phylum \\
\hline Thermosulfidibacteraeota & $\mathrm{n} / \mathrm{a}$ & 3 & Bacteria candidate phylum \\
\hline Zixibacteria & 7432 & 203 & Bacteria candidate \\
\hline Unassigned & $6,575,288$ & 54 & \\
\hline $\begin{array}{l}\text { Superphylum Candidate } \\
\text { Phyla Radiation (CPR) }\end{array}$ & 952 & $\mathrm{n} / \mathrm{a}$ & \\
\hline \multicolumn{4}{|c|}{ Recognized archaeal phylum } \\
\hline Crenarchaeota & 67,854 & 4611 & \\
\hline Euryarchaeota & 307,348 & 12,957 & Major phylum \\
\hline Korarchaeota & 5406 & 55 & Underexplored unculturable \\
\hline Nanoarchaeota & 1689 & 869 & Underexplored unculturable \\
\hline Thaumarchaeota & 39,720 & 4809 & Underexplored culturable, 1 genus, 1 type strain \\
\hline \multicolumn{4}{|c|}{$\begin{array}{l}\text { Domain archaea } \\
\text { Candidate archaea }\end{array}$} \\
\hline Aenigmarchaeota & 3324 & 42 & Underexplored unculturable DPANN \\
\hline Altiarchaeota & $\mathrm{n} / \mathrm{a}$ & 935 & Underexplored unculturable DPANN \\
\hline Diapherotrites & 1034 & 1169 & Underexplored unculturable DPANN \\
\hline Huberarchaeota & $\mathrm{n} / \mathrm{a}$ & 909 & Underexplored unculturable DPANN \\
\hline Micrarchaeota & 2844 & $\mathrm{n} / \mathrm{a}$ & Underexplored unculturable DPANN \\
\hline Nanohaloarchaeota & 3300 & $\mathrm{n} / \mathrm{a}$ & Underexplored unculturable DPANN \\
\hline Pacearchaeota & 2916 & $\mathrm{n} / \mathrm{a}$ & Underexplored unculturable DPANN \\
\hline Parvarchaeota & 371 & 201 & Underexplored unculturable DPANN \\
\hline Woesearchaeota & 6468 & $\mathrm{n} / \mathrm{a}$ & Underexplored unculturable DPANN \\
\hline $\begin{array}{l}\text { Other unculturable } \\
\text { archaea }\end{array}$ & 33,442 & 2886 & Including TACK and Asgard group \\
\hline
\end{tabular}


Table 2. Major bacterial genera with more than 100 species.

\begin{tabular}{ccccc}
\hline No. & Phyla & Genus & Total Species $^{\text {a }}$ & Total Number of Related Articles $^{\mathbf{b}}$ \\
\hline 1 & Actinobacteria & Streptomyces & 848 & 35,008 \\
2 & Firmicutes & Bacillus & 377 & 168,001 \\
3 & Proteobacteria & Pseudomonas & 254 & 162,460 \\
4 & Firmicutes & Paenibacillus & 240 & 1861 \\
5 & Firmicutes & Lactobacillus & 237 & 49,320 \\
6 & Firmicutes & Clostridium & 229 & 54,265 \\
7 & Bacteroidetes & Flavobacterium & 208 & 5555 \\
8 & Actinobacteria & Mycobacterium & 198 & 114,210 \\
9 & Proteobacteria & Vibrio & 147 & 35,798 \\
10 & Actinobacteria & Corynebacterium & 132 & 19,605 \\
11 & Firmicutes & Streptococcus & 129 & 142,792 \\
12 & Tenericutes & Mycoplasma & 127 & 28,075 \\
13 & Proteobacteria & Sphingomonas & 127 & 3051 \\
14 & Proteobacteria & Burkholderia & 122 & 11,383 \\
15 & Actinobacteria & Nocardia & 119 & 7969 \\
16 & Proteobacteria & Rhizobium & 112 & 24,085 \\
17 & Bacteroidetes & Chryseobacterium & 112 & 1278 \\
18 & Actinobacteria & Microbacterium & 110 & 1576 \\
19 & Actinobacteria & Nocardioides & 103 & 435 \\
20 & Proteobacteria & Halomonas & 102 & 1411 \\
\hline
\end{tabular}

${ }^{a}$ Based on LPSN (http://www.bacterio.net/index.html). Subspecies are not counted. ${ }^{b}$ Scopus data using the respective genus name as the keyword.

Table 3. Top ten strains according to patent counts ${ }^{\mathrm{a}}$.

\begin{tabular}{|c|c|c|c|c|}
\hline No. & Species & Phyla & Patents & Paper Citations \\
\hline 1 & $\begin{array}{l}\text { Corynebacterium glutamicum } \\
\text { ATCC } 13032\end{array}$ & Actinobacteria & 315 & 478 \\
\hline 2 & $\begin{array}{l}\text { Staphylococcus aureus subsp. aureus Rosenbach } \\
\text { ATCC } 6538\end{array}$ & Firmicutes & 184 & 610 \\
\hline 3 & $\begin{array}{l}\text { Synechocystis sp. } \\
\text { PCC } 6803\end{array}$ & Cyanobacteria & 170 & 4615 \\
\hline 4 & $\begin{array}{c}\text { Corynebacterium glutamicum } \\
\text { ATCC } 13869\end{array}$ & Actinobacteria & 131 & 59 \\
\hline 5 & $\begin{array}{l}\text { Bacillus subtilis subsp. spizizenii } \\
\text { ATCC } 6633\end{array}$ & Firmicutes & 125 & 1292 \\
\hline 6 & $\begin{array}{l}\text { Escherichia coli } \\
\text { ATCC } 25922\end{array}$ & Proteobacteria & 113 & 3594 \\
\hline 7 & $\begin{array}{l}\text { Staphylococcus aureus subsp. aureus } \\
\text { ATCC } 29213\end{array}$ & Firmicutes & 108 & 1809 \\
\hline 8 & $\begin{array}{l}\text { Brevibacterium flavum } \\
\text { ATCC } 14067\end{array}$ & Actinobacteria & 103 & 59 \\
\hline 9 & $\begin{array}{l}\text { b Candida albicans } \\
\text { ATCC } 10231\end{array}$ & Ascomycota & 93 & 488 \\
\hline 10 & $\begin{array}{l}\text { Escherichia coli } \\
\text { ATCC } 8739\end{array}$ & Proteobacteria & 79 & 315 \\
\hline
\end{tabular}




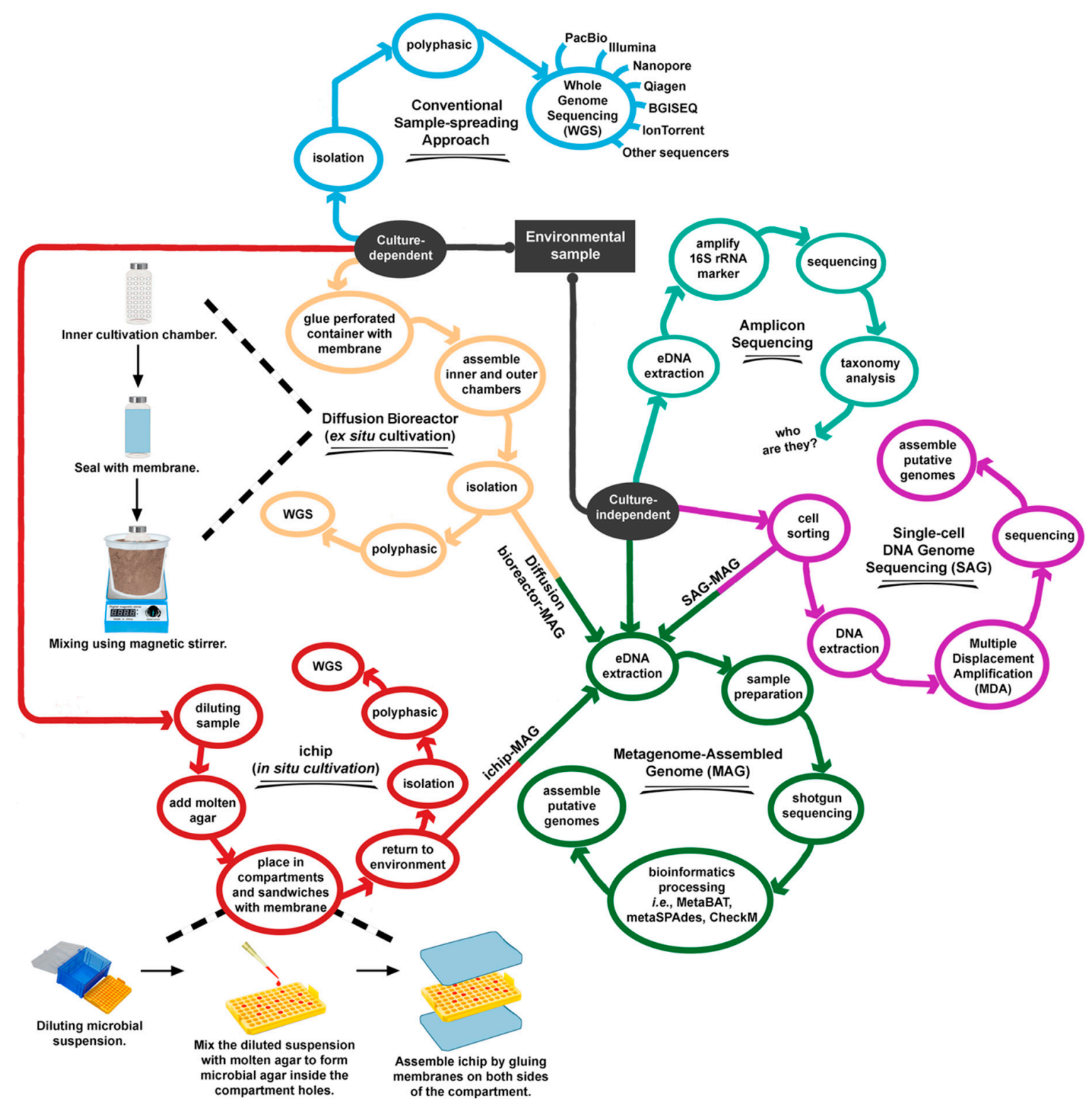

Figure 2. Overall processes of discovery of cultured and unculturable prokaryotes.

\section{Underexplored Prokaryotes}

\subsection{Definition of Underexplored Prokaryotes}

The word 'rare' is loosely defined in microbiological, taxonomical, and ecological perspectives. Microbiologists often refer to rare or underexplored prokaryotes as (i) culturable genera with limited type strains, (ii) unculturable microorganisms under laboratory conditions, or (iii) prokaryotes that present a minority population in the environment. The majority of the prokaryotes present in a sample are mostly uncultivable [13,30-32]. These underexplored prokaryotes are often referred to as 'microbial dark matter', or 'unculturable bacteria'. Rare prokaryotes are also microorganisms present as minorities in the environment whose abundance can be as low as $<0.001 \%$ of the total population [33].

\subsection{Reasons for Analysing Underexplored Prokaryotes}

Below, we give three main motivations behind the interest of research groups working in the field of underexplored prokaryotes. The first motivation is obtaining fundamental knowledge and completing a bigger picture. Trees constructed using currently known cultured taxa are only the 'tip of the iceberg' 
of the entire group of existing prokaryotes (Figure 1). Researchers accept that many prokaryotes are still hidden in the tree of life. Cultivation-independent methods (i.e., 16S rRNA amplicon sequencing, MAG, and SAG) can further expand our understanding of domain bacteria beyond those that have been cultivated [34]. Studying rare prokaryotes generates new scientific information that unveils their uniqueness. Some of these underexplored prokaryotes have atypical characteristics; for instance, unique cell wall structures [35]. A recent report suggests that rare prokaryotes play a crucial buffering role in biotic community membership and stability, besides acting as a genetic reservoir in the face of environmental perturbation [36]. It is well understood that the marine microbial community plays an enormous role in recycling global nutrients [37], and most currently established biological pathways are built on well-known prokaryotes. However, it is less understood that certain underexplored prokaryotes also have biological roles in the environment, in particular in geochemical cycles of carbon, nitrogen, and sulfur $[34,38,39]$. In the past, researchers only examined the effects of abiotic factors on overall microbial diversity, particularly the predominant taxa [40-43]. Researchers have started to investigate how environmental factors affect the diversity of the rare prokaryotes instead of the major microorganisms [44]. As we broaden horizons of underexplored prokaryotes, genomic evolution becomes better understood, and missing links in gene transfer are discovered, so that revising the tree of life may be possible.

The second primary motivation of working in the field of underexplored bacteria is their association with health and diseases. Researchers suspect that certain underexplored bacteria are related to infections in humans, animals, or plants. For example, the candidate (or candidatus in Latin) Liberibacter asiaticus is pathogenic to potato, carrot, tomato, and citrus [45]. The threat from these bacteria is so severe that the US Environmental Protection Agency (EPA) is currently in the process of allowing citrus growers to spray antibiotics to control pathogenic Liberibacter species [46]. In humans, the growth of an underexplored prokaryote, namely candidate Borkfalki ceftriaxensis, was observed following antibiotic treatment with ceftriaxone.

Additionally, it is now understood that other than viruses, bacteriophages, fungi, and bacteria, the candidate phyla radiation (CPR) superphylum group of bacteria interact with each other in the human oral environment and collectively may impact human health [34]. On the other hand, the search for new antibacterials also needs to continue. It needs to be determined whether underexplored microorganisms are important sources of new antibacterial agents. The US Government Defense Advanced Research Projects Agency (DARPA) conceptualized the Pathogen Predators Research Program with an enacted budget of 3.4 billion USD for 2019. One of DARPA's projects was searching for predatory bacteria against pathogens [47]. To date, Bdellovibrio bacteriovorus (from a genus consisting of four type strains) and Micavibrio aeruginovorus (from a monotypic genus) are the only predatory bacteria known to prey upon >100 different human pathogens [48-50].

The third primary motivation is the new applications-Blue Ocean Strategy. Protein sequences of underexplored prokaryotes exhibit low similarities to other well-established proteins. The exploration of underexplored prokaryotes and their macromolecules and natural products is regarded as the 'blue ocean strategy' in science (a term coined from a book of the same title by Mauborgne and Kim [51]). The author defined the 'blue ocean strategy' as "the simultaneous pursuit of differentiation to open up a new market space and create new demand". Therefore, discovering new strains or native and novel macromolecules may establish new, if not, better applications. In some reports, the total number of genes annotated as hypothetical proteins represent half of the total number of genes [52]. Some archaeal genomes had up to $80 \%$ hypothetical proteins [53]. It would be interesting to identify new potential applications of these unknown genes. In addition, exploring rare prokaryotes is an opportunity for an offensive patent strategy of potentially lucrative novel bioeconomy.

\subsection{Why Are Great Proportions of Prokaryotes Unculturable?}

Researchers blame the prokaryotes since much about them remains 'black box information' or non-reproducible under the designated laboratory setup. For example, (i) cells may need unknown 
special culture requirements: uncommon nutrients, a narrow temperature or $\mathrm{pH}$ range, or unusual compounds to support their growth. (ii) Cells from the environment are in the dormancy stage, and none of the resuscitation approaches can make them appear on the Petri dish, and (iii) having a smaller genome size causes most candidate CPR to lack numerous biosynthesis pathways, to be absent of ATP synthase, and to lack the electron transport chain complex [54]. As a result, Dombrowski et al. [55] concluded that CPR and DPANN members are unable to grow individually but, rather, rely on resources contributed by neighboring bacteria through symbiosis, parasitism, or other relationships. Despite such biological interactions also existing in culturable microorganisms [56], CPR and DPANN members are relatively more delicate.

\subsection{How Should Underexplored Prokaryotes Be Cultured?}

It is not impossible to isolate underexplored prokaryotes from the environment. From the authors' analysis using data from the Deutsche Sammlung von Mikroorganismen und Zellkulturen (DSMZ), at least 1000 genera are single-species representatives (monotypic or monospecies) which were once categorized as 'unculturable' (Table 4). Although some monotypic strains require stringent isolation or cultivation strategies, many of the bacteria are not at all demanding to cultivate. Although the suggestions provided hereafter are not new, however, microbiologists in their early career may be unaware of them.

The first suggestion is paying attention to isolation and growth preparation. Autoclaving agar with phosphate remarkably lowers the total number of colonies that grow on the agar plates [57]. Agar contains some inhibitors that prevent the growth of some prokaryotes; gelrite is a better solidification agent. The enrichment of any environmental sample (e.g., soil or sediment) using atypical chemicals may enhance the probability of isolating rare prokaryotes. For example, Aanderud [58] used heavy water $\left(\mathrm{H}_{2}{ }^{18} \mathrm{O}\right)$ to rewet soil samples. Interestingly, after introduction of heavy water, the abundance of initially recognized rare microorganisms increased considerably, from hardly detectable to the dominant proportion of the community.

The second suggestion is: reconsider sampling sites. In order to increase the success rate of discovering undomesticated species, individuals who conduct the sampling should perhaps consider using some hard-to-reach locations where human activities are at a minimum. For example, hydrothermal vents in ocean basins, boiling geothermal springs, and caves, such as those at Mount Roraima in South America; rainforests, such as the deep Amazon or Malaysia's Kinabalu National Park; parched dry places, such as the Atacama Desert colourful lakes, such as those of Indonesia's Kelimutu volcano; or deep-cold places, such as Antarctica (below $2.75 \mathrm{~km}$ in depth). Members of the Extreme Microbiome Project are interested in poly-extremophiles, for example, thermophiles in the Hell gas crater of Turkmenistan, and halophiles in Lake Hiller of Australia [59]. Readers are referred to a recent review article that discusses current knowledge on extremophiles [60].

The third suggestion is modifying cultivation strategy. (i) In situ cultivation: If possible, researchers could consider using a device such as isolation chips (ichips) to maximize the number of individual colonies $[61,62]$. The idea behind the ichip is to dilute the environmental samples using molten agar, trapping each cell into a hollow compartment sealed with a membrane, and returning the ichip to the environment (Figure 2). Using the ichip, a new class of antibiotics (teixobactin) was discovered from an unculturable bacterium, Eleftheria terrae [47]. (ii) Ex situ cultivation: Recently, Chaudhary et al. [63] described a new bacterial cultivation device termed as a diffusion bioreactor (Figure 2). Using this approach, the authors isolated 35 previously uncultured strains from phyla Proteobacteria, Firmicutes, Actinobacteria, and Bacteroidetes. The diffusion bioreactor is more flexible than that of the in situ ichip method. As the diffusion bioreactor is performed in the laboratory, researchers have a better selection of abiotic or experimental parameters, for instance, $\mathrm{pH}$, temperature, moisture, nutrients, and timing. Lately, Sun et al. [64] discussed several strategies to improve archaeal cultivation. 
Table 4. Selected monotypic bacteria with genome sequencing information

\begin{tabular}{|c|c|c|c|c|c|c|}
\hline Phylum/Family & Monotypic Name & Source & Growth Condition & Genome Size $(\mathbf{M b})$ & $\begin{array}{l}\text { NCBI Genome } \\
\text { Accession no. }\end{array}$ & Ref. \\
\hline Abditibacteriota/Abitibacteriaceae & Abditibacter iumutsteinense & Antartic soil & psychrophile & 3.61 & GCA_002973605 & [28] \\
\hline Firmicutes/Staphylococcaceae & Abyssicoccus albus & deep sea sediment & mesophilic & 1.8 & GCA_003815035 & [65] \\
\hline Actinobacteria/Micrococcaceae & Acaricomes phytoseiuli & predatory mite & mesophile, slow grower & 2.4 & NZ_AQXM00000000 & [66] \\
\hline Firmicutes/Ruminococcaceae & Acetanaerobacterium elongatum & wastewater & mesophile, anaerobe & 2.9 & NZ_FNID00000000 & [67] \\
\hline Firmicutes/Clostridia & Acetatifactor muris & cecum of mouse & mesophile, anaerobe & 6.0 & NZ_OFSM00000000 & [68] \\
\hline Proteobacteria/Acetobacteraceae & Acidicaldus organivorans & hot spring & thermophile & 2.89 & GCA_000759655 & [69] \\
\hline Actinobacteria/Acidimicrobiaceae & Aciditerrimonas ferrireducens & solfataric soil & thermophile & 1.18 & GCA_001311945 & [70] \\
\hline Chloroflexi/Anaerolineaceae & Bellilinea caldifistulae & thermophilic digester sludge & thermophile, anaerobe & 3.66 & NZ_LGHJ00000000 & [71] \\
\hline Firmicutes/Sporolactobacillaceae & Caenibacillus caldisaponilyticus & Acidic compost & thermophile & 3.35 & GCA_002003465 & [72] \\
\hline Firmicutes/Thermodesulfobiaceae & Caldanaerovirga acetigignens & hot spring & thermophile, anaerobe & 2.26 & GCA_900142995 & [73] \\
\hline Fibrobacteres/Chitinispirillaceae & Chitinispirillum alkaliphilum & hypersaline soda lake & mesophile, anaerobic & 4.4 & GCA_001045525 & [74] \\
\hline Proteobacteria/Hyphomicrobiaceae & Dichotomicrobium thermohalophilum & solar lake & thermophile & 2.99 & NZ_QXDF00000000 & [75] \\
\hline Actinobacteria/Pseudonocardiaceae & Goodfellowiella coeruleoviolacea & soil & mesophile & 9.3 & GCA_000715825 & {$[76]$} \\
\hline Proteobacteria/Rhodobacteraceae & Hwanghaeicola aestuarii & tidal sediment & mesophile & 4.54 & GCA_003253995 & [77] \\
\hline Actinobacteria/Pseudonocardiaceae & Herbihabitans rhizosphaerae & soil & mesophile & 6.64 & GCA_004216555 & [78] \\
\hline Proteobacteria/Rhodobacteraceae & Jhaorihella thermophila & coastal hot spring & moderate thermophile & 3.77 & GCA_900108275 & [79] \\
\hline Synergistetes/Synergistaceae & Jonquetella anthropi & human cyst & mesophile, anaerobe & 1.68 & NZ_AGRU00000000 & [80] \\
\hline Actinobacteria/Micromonosporaceae & Krasilnikovia cinnamomea & soil & mesophile & 7.62 & GCA_004217545 & [81] \\
\hline Bacteroidetes/Cytophagaceae & Leadbetterella byssophila & cotton waste compost & mesophile & 4.06 & СР002305 & [82] \\
\hline Proteobacteria/Rhodobacteraceae & Mangrovicoccus ximenensis & mangrove forest & halotolerant, mesophile & 5.97 & GCA_003056725 & [83] \\
\hline Proteobacteria/Beijerinckiaceae & Methyloferula stellata & acidic peat soil & psychrophile & 4.24 & NZ_ARWA00000000 & [84] \\
\hline Proteobacteria/Rhodobacteraceae & Monaibacterium marinum & sea water & mesophile & 3.73 & GCA_900231835 & [85] \\
\hline Bacteroidetes/Flammeovirgaceae & Nafulsella turpanensis & soil & mesophile & 4.81 & GCA_000346615 & [86] \\
\hline Bacteroidetes/Sphingobacteriaceae & Nubsella zeaxanthinifaciens & fresh water & mesophile & 4.25 & GCA_003313335 & [87] \\
\hline Chloroflexi/Anaerolineaceae & Ornatilinea apprima & deep well & thermophile, anaerobe, & 4.35 & GCA_001306115 & [88] \\
\hline Firmicutes/Clostridiaceae & Oxobacter pfennigii & rumen of cattle & mesophile, anaerobe & 4.51 & GCA_001317355 & [89] \\
\hline Bacteroidetes/Sphingobacteriaceae & Pelobium manganitolerans & sludge of a mine & mesophile & 3.93 & GCA_003609575 & [90] \\
\hline Planctomycetes/Planctomycetaceae & Schlesneria paludicola & sphagnum peat & mesophile & 8.67 & GCA_000255655 & [91] \\
\hline
\end{tabular}




\subsection{Exploring Unculturable Prokaryotes Using Metagenome-Assembled Genomes (MAG)}

Even with intensive isolation efforts, a certain proportion of prokaryotes escape cultivation-for example, candidate phyla, unculturable superphylum, such as the bacterial CPR and archaeal DPANN, and other unexplored or unknown phyla (Figure 1). The exact number of unexplored phyla is unknown. Examples of a few candidate phyla are listed in Table 1, and this number is expected to rise. The naming of uncultured taxa could be confusing due to inconsistencies in nomenclature [92], dynamic updates and renaming, and differences of information in major databases, for instance, those of the NCBI Taxonomy, Silva, and Genome Taxonomy Database (Table 1) [2,8].

To date, unculturable prokaryotes bacterial CPR membership has been conferred to more than 70 Candidate phyla [92]. There are many putative archaea phyla identified via culture-independent approaches $[53,64]$. The cumulative $16 \mathrm{~S}$ rRNA amplicon sequencing and genomic data have led to the proposal of several archaea superphyla. For instance, DPANN is the largest archaea superphyla with $>24,000$ deposited 16S rRNA sequences listed in NCBI taxonomy and Silva databases (September 2019). The readers can refer to a recently published review article on DPANN (candidate Aenigmarchaeota, Altiarchaeota, Diapherotrites, Hadesarchaeaeota, Huberarchaeota, Micrarchaeota, Nanohaloarchaeota, Pacearchaeota, Parvarchaeota, and Woesearchaeota) for more insights on the genomic features, lifestyle, and evolution [55]. Other unculturable archaea superphyla include Asgard (also known as Asgardaeota) and TACK (also known as Proteoarchaeota) [64]. The TACK superphyla group consisted of Nitrosopumilales, Nitrosotalea, Nitrosophaerales, Nitrospcaldales, Geothermarchaeota, Aigarchaeota, Bathyarchaeota, Marsarchaeota, Nezhaarchaeota, Geoarchaeota, and Verstraetearchaeota. However, the TACK is undergoing dynamic membership updates and renaming, and the taxonomy affiliation of certain members are uncertain.

MAG is one of the most effective ways to glimpse the genomes of unculturable prokaryotes. Anantharaman et al. [33] described 47 newly discovered phyla using 2540 reconstructed MAGs and elucidated that microbiome biological pathways are cross-linked. Danczak et al. [93] recently discussed the putative functions of 32 already known CPR Candidate phyla in carbon processing and nitrogen cycling. An impressive large-scale reconstruction of 7903 MAGs was performed, which provided the first genomic representatives of new rare candidate bacteria and archaea [17]. Accordingly, all the assembled genomes have at least $50 \%$ completeness, and nearly half of the total MAGs are $\geq 90 \%$ complete with less than 5\% contamination. In a separate study, MAG analyses of two archaea from a hyperthermal hot spring identified unrecognized methane-metabolising sequences outside of the phylum Euryarchaeota [94]. In another work, Kadnikov et al. [95] recovered a complete genome of the candidate phylum BRC1 using MAG analysis of a deep subsurface thermal aquifer. For more information, readers can refer to a recent review article by Quince et al. [96] that covers experimental design, sampling, and analysis using shotgun metagenomics for MAG. A summary of MAG-related research and bioinformatics tools is given in Table 5. CheckM is a tool used to determine genome completeness and identify contaminant sequences [97].

Table 5. Selected publications and major findings related to metagenomic assembled genomes (MAGs).

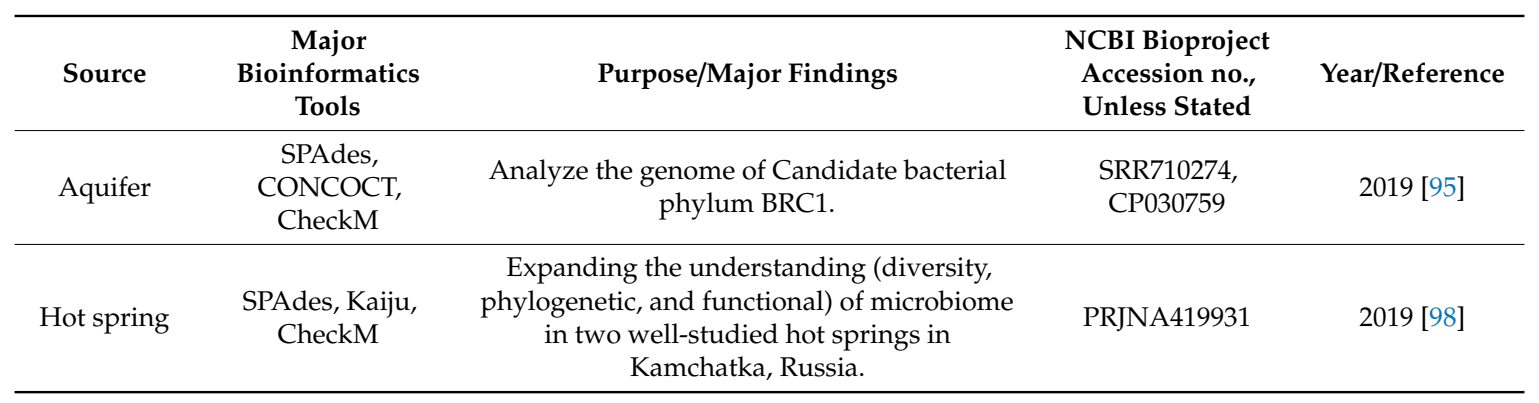


Table 5. Cont.

\begin{tabular}{|c|c|c|c|c|}
\hline Source & $\begin{array}{l}\text { Major } \\
\text { Bioinformatics } \\
\text { Tools }\end{array}$ & Purpose/Major Findings & $\begin{array}{l}\text { NCBI Bioproject } \\
\text { Accession no., } \\
\text { Unless Stated }\end{array}$ & Year/Reference \\
\hline Aquifer & $\begin{array}{l}\text { bbduk in the } \\
\text { bbmap package, } \\
\text { SPAdes, VizBin, } \\
\text { CheckM }\end{array}$ & $\begin{array}{l}\text { Assembled the genome of Rhodoferax sp. } \\
\text { However, the authors were not able to } \\
\text { confirm that this bacterium can degrade } \\
\text { sulfolane in the contaminated aquifer. }\end{array}$ & $\begin{array}{l}181102 \text { (JGI } \\
\text { IMG/ER) }\end{array}$ & 2019 [100] \\
\hline Soda lakes & $\begin{array}{c}\text { BBnorm, } \\
\text { MetaSpades, } \\
\text { MetaBat, CheckM }\end{array}$ & $\begin{array}{l}\text { Used metagenomics and metaproteomics to } \\
\text { provide a comprehensive molecular } \\
\text { characterization of a phototrophic microbial } \\
\text { mat microbiome. }\end{array}$ & PRJNA377096 & 2019 [101] \\
\hline $\begin{array}{l}\text { Lab-scale } \\
\text { reactor }\end{array}$ & $\begin{array}{l}\text { CLC de novo } \\
\text { assembler, CheckM }\end{array}$ & $\begin{array}{l}\text { Explaining the shifts in microbial community } \\
\text { structures using } 16 \mathrm{~S} \text { rRNA metagenome, } \\
\text { MAGs, and metaproteomic data. }\end{array}$ & PRJNA471375 & 2019 [102] \\
\hline $\begin{array}{l}\text { Artificial } \\
\text { acid mine } \\
\text { drainage }\end{array}$ & $\begin{array}{l}\text { SPAdes, CheckM, } \\
\text { ESOM }\end{array}$ & $\begin{array}{c}\text { Describe taxonomy and ecological role of a } \\
\text { new order Ca. Acidulodesulfobacterales } \\
\text { (Sva0485 clade). }\end{array}$ & PRJNA517999 & 2019 [103] \\
\hline Freshwater & $\begin{array}{l}\text { SolexaQA++, } \\
\text { Scythe, IDBA-UD, } \\
\text { MetaBAT, MASH, } \\
\text { MiGA, CheckM }\end{array}$ & $\begin{array}{l}\text { Explain poorly understood Ca. } \\
\text { Pelagibacterales (SAR11 clade IIIb). }\end{array}$ & $\begin{array}{l}\text { PRJNA495371, } \\
\text { PRJNA214105, } \\
\text { PRJNA497294 }\end{array}$ & 2019 [104] \\
\hline Hot spring & $\begin{array}{l}\text { IDBA, MaxBin, } \\
\text { CheckM }\end{array}$ & $\begin{array}{l}\text { Reconstruct the genome of cyanobacteria } \\
\text { Fischerella thermalis. }\end{array}$ & NA382437 & 2018 [109] \\
\hline Hot spring & $\begin{array}{l}\text { metaSPAdes, } \\
\text { CONCOCT, SNAP, } \\
\text { CheckM }\end{array}$ & $\begin{array}{l}\text { To relate MAGs' extracellular electron } \\
\text { transfer systems with iron redox-based } \\
\text { metabolisms }\end{array}$ & $\begin{array}{l}3300010938 \text { and } \\
3300014149 \\
\text { (IMG/M ER) }\end{array}$ & 2018 [110] \\
\hline Cow rumen & $\begin{array}{l}\text { MetaBAT, dRep, } \\
\text { CheckM }\end{array}$ & $\begin{array}{l}\text { Improve the understanding of taxonomic } \\
\text { structure of rumen microbiome. To mine } \\
\text { novel carbohydrate degrading enzymes. }\end{array}$ & PRJEB21624 & 2018 [111] \\
\hline $\begin{array}{l}\text { Offshore } \\
\text { station }\end{array}$ & $\begin{array}{l}\text { Refers to original } \\
\text { articles }\end{array}$ & $\begin{array}{l}\text { Compare SAG and MAG for samples } \\
\text { collected from the same site. }\end{array}$ & $\begin{array}{l}\text { PRJEB21451, } \\
\text { LIAK00000000- } \\
\text { LIDO00000000 }\end{array}$ & $2018[18,112]$ \\
\hline Aquifer & $\begin{array}{c}\text { MetaBAT, } \\
\text { AMPHORA2 }\end{array}$ & $\begin{array}{l}\text { Propose the carbon and nitrogen cycling } \\
\text { functions for } 71 \text { putative CPR genomes. }\end{array}$ & SRX2896383 & 2017 [93] \\
\hline $\begin{array}{l}\text { Metadata } \\
\text { obtained } \\
\text { from SRA } \\
\text { database }\end{array}$ & $\begin{array}{l}\text { CLC de novo } \\
\text { assembler, } \\
\text { MetaBAT, } \\
\text { CheckM, RefineM }\end{array}$ & $\begin{array}{c}\text { Expand the understanding of phylogenetic } \\
\text { and genomes of uncultivated bacteria and } \\
\text { archaea. }\end{array}$ & PRJNA34875 & 2017 [17] \\
\hline
\end{tabular}




\section{Potential Applications of Underexplored Prokaryotes}

\subsection{Potential Applications of Culturable Rare Prokaryotes}

A recent study has shown that depths of $6-11 \mathrm{~km}$ below sea level are heavily polluted by microplastic (fragment size $\leq 5 \mathrm{~mm}$ ) [113]. A recent review article summarized current milestones in the use of microbial enzymes for modifying or degrading different categories of plastics, for instance, polyurethane and polyethylene terephthalate (PET) [114]. Unfortunately, the degradation process of highly crystallized and packed plastics is still considered slow and ineffective. Readers are advised to read a review on marine microbial adaptation, interaction, and degradation of microplastics [115]. The biodegradation of recalcitrant plastics involves various groups of enzymes; including cutinases, laccases, manganese peroxidases, lignin peroxidases, alkane hydroxylases, tannases, hydroquinone peroxidases, ureases, esterases, lipases, proteases, and polyester hydrolases, although each with a different extent of degradations [114]. Enzymes from various genera have been described to have some form of plastic degrading ability. Delftia, Thermobifida, and Ideonella being among the genera with limited type strains [114]. Ideonella sakaiensis is able to use PET as carbon source [116]. Enzymes from I. sakaiensis and Thermobifida fusca have been extensively examined with regards to the aspects of enzyme catalytic mechanism, structure, and function [117-120]. In nature, PETases (PET hydrolase) are esterase active on ester bonds [116,120]. In a separate work, Danso et al. (2018) mined 853 gene sequences using a metagenomics approach and showed that PETases are mainly distributed in culturable Actinobacteria, Proteobacteria, and Bacteroidetes [121], and among the sources, Caldimonas and Methylibrium can be further explored. Additionally, PETase homologues are also found in other groups of bacteria [118].

Efforts have been invested in harnessing rare marine Actinobacteria. Examples of underexplored Actinobacteria are Actinoalloteichus, Salinispora, Marinactinospora, and Actinosynnema. These prokaryotes produce active compounds with cytotoxic, antibacterial, antifungal, and antimalarial activity [122]. The phylum Actinobacteria is one of the largest phyla in terms of total isolates and sequences deposited in databases (Figure 1, Table 1). However, the isolation and discovery of new Actinobacteria species are continuing. In a large-scale screening, Idris et al. [123] elucidated that $16 \%$ of the total sequence reads associated to this phylum could only be assigned up to class level based on the EzTaxon-e database, and these new taxa had relatively low similarity to already-described Actinobacteria genera.

Lambrechts and Tahon [124] recently summarized the progress of Antarctic microbiology studies and listed many monotypic genera of rare bacteria. More attention should be given to psychrophilic microorganisms, as their enzymes are of potential use in biotechnology, particularly for applications that require lower temperatures [125]. There are many underexplored psychrophilic prokaryotes; for example, a monotypic Raineyella antarctica was recently isolated and sequenced [126]. Sheridan et al. [127] described Rhodoglobus 16 years ago while Li et al. [128] first reported monotypic Marisediminicola antarctica ca. 10 years ago. Unfortunately, neither genera have received much attention. Few researchers are interested in studying psychrophiles, possibly because many of these bacteria grow slowly and most of their proteins (enzymes) are sensitive to higher temperatures.

Industrial enzymes, such as hydrolases for starch, cellulose, hemicellulose, lipids, and esters, are biocatalysts that have been extensively targeted using culture-based approaches. Many rare bacteria type strains harbour interesting genes, and a few are listed here. Melioribacter roseus is a facultative anaerobe and a thermophile that is rich in various glycosyl hydrolase (GH) genes [129-131]. The bacteria Siansivirga zeaxanthinifaciens, a mesophile, and Alkalitalea saponilacus, an anaerobe and alkalophile, also harbour a broad range of GHs [132-135]. All the bacteria mentioned above are monotypic of their respective genus. Jeotgalibacillus is another example of an underexplored genus whose enzymes may be of use [136]. Liew et al. [137] recently elucidated that J. malaysiensis produces glucose-tolerant $\beta$-glucosidase.

Rhodothermaceae (thermophilic), Rubricoccaceae (mesophilic), Salisaetaceae (halophilic), and Salinibacteraceae (halophilic) are families of the order Rhodothermales. To date, this order consists of ten genera, each with no more than three species. The order is small, having only 16 validly described 
type strains. Rhodothermus spp. produce important cellulosic and hemicellulosic hydrolases [138,139]. However, none of the other genera in the order Rhodothermales have been studied for counterpart enzymes. Lately, Park et al. [140] isolated Roseithermus sacchariphilus gen. nov., sp. nov. (strain MEBiC09517 ${ }^{\mathrm{T}}$ ) from sediment collected from a coastal area. Due to the high genome-to-genome similarity, our isolated bacterium Rhodothermaceae RA is the subspecies of strain MEBiC09517 ${ }^{\mathrm{T}}[141,142]$. The bacterium $R$. sacchariphilus RA has 57 glycosyl hydrolase sequences. We have cloned and characterized two novel xylanase enzymes $[143,144]$. For one of the novel enzymes that we characterized, the protein sequence showed less than $50 \%$ sequence identity to well-characterized counterpart enzymes. The authors believe that all members of the order Rhodothermales should be given more consideration for the discovery of enzymes.

The International Society of Rare Sugar (http://www.isrs.kagawa-u.ac.jp) has defined rare sugars as monosaccharides and their derivatives that rarely exist in nature [145]. These fine chemicals (i.e., D-allose, D-psicose, D-gulose, D-sorbose, and L-ribose) are valuable and have numerous applications in food products and sweeteners, pharmaceuticals, and agriculture [145-147]. The conversion of natural sugars to rare sugars involves several enzymatic reactions involving isomerases, epimerases, and oxidoreductases [145]. The majority of enzymes already applied in the industry have been sourced from cultured bacteria. To the best of our knowledge, attempts of finding underexplored culturable prokaryotes as well as gene-mining using a metagenomic approach to produce rare sugar are scarce [147].

Many monotypic bacteria remain to be discovered and could provide insights into fundamental sciences and offer possible biotechnological applications. Table 4 summarizes some monotypic bacteria with genome information. Other records of monotypic bacteria and genera are available on the LPSN database and Wikipedia (http://www.wikipedia.org; keyword: monotypic bacteria. Note: the list may not be auto updated). Readers who wish to have access to a periodically updated list of prokaryotes can refer to Prokaryotic Nomenclature on the official webpage of DSMZ.

\subsection{Potential Research Topics in Unculturable Prokaryotes}

For culturable rare prokaryotes, we store the cells on Petri dishes or freeze them as stock cultures. This strategy is different from exploiting resources from unculturable prokaryotes since we do not have cells of unculturable prokaryotes. Researchers only retain extensive digital information (contigs or scaffolds, annotated genes, or sequences of proteins) and a limited volume of eDNA. The easiest way to explore biological resources (genes and proteins) mined in MAGs or SAGs is by synthesizing the complete genes using commercial service providers, cloning the genes in a suitable vector, expressing the genes as recombinant proteins, examine the biochemical functions, or analyze the protein structures by methods such as X-ray crystallization. Although synthesizing several genes is affordable for most laboratories, this workflow is not flawless as the selection of the genes is pivotal. It is not always possible to pinpoint the right targeted genes due to knowledge limitations, or the expressed recombinant proteins are neither active nor function as anticipated.

Ocean and coastal bodies are the most significant reservoirs of diverse microbes and important sources for the discovery of prokaryotes. Tara Oceans is a well-known global ocean expedition involving hundreds of researchers. MAG information from this project is publicly available [107]. Other MAG data obtained from various environments are also deposited in public databases, such as the NCBI. By exploring putative genes of interest generated in-house or from sources such as the Tara Oceans expedition, researchers will have ample genes that encode biocatalysts or macromolecules that may be applicable in biotechnology. Examples of metagenome-derived biocatalysts and proteins, both from the common and underexplored prokaryotes, are listed hereafter; haloalkane dehalogenase, esterase, $\beta$-glucanase, keratinase, exonuclease, and endoglucanase [148-153]. Other examples of recent work using MAGs to mine biocatalysts and proteins are listed in [150,154]. Readers are encouraged to read some excellent review articles on the topic of MAGs [155,156]. 


\section{Limitations and Future Directions of Prokaryote Discovery}

The authors agree with the opinion of Garza and Dutilh [157] that scientists have only scratched the surface of the vast microbial world. The total number of phyla in the prokaryotic domain remains unknown (Figure 1). This review does not intend to exaggerate the importance of underexplored prokaryotes. We acknowledge that prokaryotes such as Bacillus are still one of the best workhorses for industrial applications. One needs to understand that there are many obstacles and limitations to exploring rare prokaryotes, despite the rewards it may offer, and a few will be discussed here.

Using single-cell genome amplification to explore unculturable prokaryotes is not straightforward. Hedlund et al. [158] reported that SAG is not an ideal approach if the environmental sample is too complicated. However, there have been a few successful applications. In most cases, genome assembles derived from SAG is shorter than MAG, depending on the type of samples [18,21,159]. On the other hand, SAG yields more focused reads than the wider MAG. As such, methods integrating SAG and MAG, such as the JGI's innovative microfluidic-based mini-metagenomic method, offers a more accurate complete genome [22]. However, not all laboratories have the resources to use microfluidic technology.

The invention of the ichip is interesting and nothing short of ingenious. Furthermore, all laboratories can convert affordable plastic pipette tip racks into a homemade ichip. According to the descriptions in Berdy et al. [160], it is possible to obtain a single type of cell or combination of a few strains in each chamber. We speculate that pairing the ichip with MAG would be much easier and cheaper than SAG-MAG methods (Figure 2). However, this concept has not been experimentally proven.

Prokaryote genomes vary in size; for example, candidatus Carsonella ruddii has a tiny size of $0.17 \mathrm{Mb}$, while the Sorangium cellulosum strain So0157-2 has a very large size of $14.78 \mathrm{Mb}$ [161,162]. The mean genome size for prokaryotes is $\sim 3.7 \mathrm{Mb}$ (https://www.ezbiocloud.net) [163]. Based on statistical analysis, many Actinomycetes strains that produce important secondary metabolites have large genomes, approximately $>8 \mathrm{Mb}$ [122]. According to the article, the coding capacity increases with genome size [122]. It is not uncommon that prokaryotes with genomes smaller than $8 \mathrm{Mb}$ also exhibit a complete set of secondary metabolite gene clusters as well as other important industrially-applicable proteins. However, unculturable CPR and the DPANN superphyla have very small genomes because they have minimal biosynthetic capacities $[52,54,55]$. Therefore, some unculturable prokaryotes, especially those with extraordinarily small genomes, may encode lesser industrially applicable proteins, thus, limiting their exploitation in biotechnology. The genus Bacillus is a favorite source of industrial enzymes because it has a sufficiently large genome and, thus, produces a broad range of proteins, compared to its counterpart Anoxybacillus, whose genome is approximately $50 \%$ shorter. Some of the commonly found genes, for instance enzyme CGTase, is present in Bacillus and Geobacillus, but absent in taxonomically-related Anoxybacillus due to genome shrinking $[164,165]$. Nevertheless, this does not mean that prokaryotes with a small genome have no potential use. For example, Caldicellulosiruptor saccharolyticus is an excellent thermophilic candidate for $\mathrm{H}_{2}$ production and plant biomass degradation, despite its genome $(2.9 \mathrm{Mb})$ being smaller than the mean size of prokaryote genomes [166]. Many hyperthermophilic archaea in general have smaller genomes, for instance, the genome size for Pyrococcus spp. is $\sim 1.9 \mathrm{Mb}$ [167]. DNA polymerase from Pyrococcus is one of the high-fidelity enzymes that has been long commercialized by New England Biolabs.

We want to emphasize that MAG is not a magic staff. MAG is still not a common approach that all laboratories can perform. Novel sequences can be found from MAGs, even when a pure culture is not available. It is possible that the assembly of reads is imperfect, and this can create an artefact gene. The translated recombinant protein can malfunction due to a mutation at important positions due to the artefact in the gene. Unfortunately, even with properly assembled genes, for instance, those identified in high-quality WGS, various sophisticated persistent problems remain unsolved; for example, failure due to protein misfolding in the expression hosts. In addition, determining the roles of hypothetical proteins (assembled in WGS, MAG, or SAG) is relatively more costly and time-consuming. Deducing the protein's function may require additional work, such as transcriptomic and in silico 
functional prediction. The crystallization of hypothetical proteins to identify clues from the protein structure is another potential method. Readers can refer to recent work on the discovery of hypothetical proteins [168-171]. The numbers of hypothetical proteins will expand rapidly as more underexplored genomes are sequenced; however, the speed to understand proteins' functions remain sluggish [53].

\section{Conclusions}

We believe that all creatures, including underexplored prokaryotes, have the potential for as-yet-unknown purposes. The cultivation of underexplored prokaryotes is somewhat challenging; yet, with the right experimental approach, a proportion of these cells can be isolated and grown in laboratories. Researchers can consider modifying their standard laboratory practices and try some different methods for selecting sampling sites, resuscitation approaches, enrichment techniques, or explore the state-of-the-art cultivation methods, for instance in situ and ex situ cultivation. Different DNA sequencing strategies, i.e., WGS, SAG, and MAG, allow researchers to glimpse the genomic contents of underexplored prokaryotes. Overall, it appears that the MAG approach is a more reliable strategy for discovering unculturable microbes. If assembly is performed carefully, MAG methods can be used to generate accurate genome information from uncultivated bacteria as well as underexplored culturable bacteria and will eventually become a standard tool. However, functional-based metagenomics remains expensive and is not affordable on a larger scale. The quality of MAGs is highly dependent on the type and preparation of samples, and MAG requires computational capacity for processing large quantities of sequencing read data and downstream analyses. It is believed that exploring rare prokaryotes is interesting, yet requires due diligence and wise decision-making to overcome all possible challenges.

Author Contributions: Conceptualization: K.M.G. and U.M.K; writing-original draft preparation: K.M.G. and S.S.; writing—review and editing: K.M.G., S.S., K.-G.C., C.S.C., S.I.A., M.H.S., I.I.Z., and U.M.K; validation: U.M.K; visualization: U.M.K.

Funding: This research was funded by FRGS grant (FRGS/1/2019/STG03/UTM/02/1); Universiti Teknologi Malaysia under Grants 09J62, 18H36, and 16H89; BBSRC (UK)-Ministry of Education (Malaysia) Newton Ungku Omar Fund (UK-SEA-NUOF) under Grant BB/P027717/1 and 4B297; the University of Malaya under Grant High Impact Research GA001-2016 and GA002-2016; and Malaysia Genome Institute.

Conflicts of Interest: The authors declare no conflict of interest.

\section{References}

1. Wang, S.; Chen, Y. Phylogenomic analysis demonstrates a pattern of rare and long-lasting concerted evolution in prokaryotes. Commun. Biol. 2018, 1, 12. [CrossRef] [PubMed]

2. Parks, D.H.; Chuvochina, M.; Waite, D.W.; Rinke, C.; Skarshewski, A.; Chaumeil, P.A.; Hugenholtz, P. A standardized bacterial taxonomy based on genome phylogeny substantially revises the tree of life. Nat. Biotechnol. 2018, 36, 996-1004. [CrossRef] [PubMed]

3. Goris, J.; Konstantinidis, K.T.; Klappenbach, J.A.; Coenye, T.; Vandamme, P.; Tiedje, J.M. DNA-DNA hybridization values and their relationship to whole-genome sequence similarities. Int. J. Syst. Evol. Microbiol. 2007, 57, 81-91. [CrossRef] [PubMed]

4. Qin, Q.L.; Xie, B.B.; Zhang, X.Y.; Chen, X.L.; Zhou, B.C.; Zhou, J.; Oren, A.; Zhang, Y.Z. A proposed genus boundary for the prokaryotes based on genomic insights. J. Bacteriol. 2014, 196, 2210-2215. [CrossRef] [PubMed]

5. Parker, C.T.; Tindall, B.J.; Editors, G.M.G. International Code of Nomenclature of Prokaryotes. Int. J. Syst. Evol. Microbiol. 2019, 69, S1-S111.

6. Trujillo, M.E.; Oren, A.; Garrity, G.M. Preparation of the Validation Lists and the role of the List Editors. Int. J. Syst. Evol. Microbiol. 2019, 69,3-4. [CrossRef]

7. Reimer, L.C.; Vetcininova, A.; Carbasse, J.S.; Söhngen, C.; Gleim, D.; Ebeling, C.; Overmann, J. BacDive in 2019: Bacterial phenotypic data for high-throughput biodiversity analysis. Nucleic Acids Res. 2019, 47, D631-D636. [CrossRef] 
8. Yilmaz, P.; Parfrey, L.W.; Yarza, P.; Gerken, J.; Pruesse, E.; Quast, C.; Schweer, T.; Peplies, J.; Ludwig, W.; Glöckner, F.O. The SILVA and all-species Living Tree Project (LTP) taxonomic frameworks. Nucleic Acids Res. 2014, 42, D643-D648. [CrossRef]

9. Mukherjee, S.; Stamatis, D.; Bertsch, J.; Ovchinnikova, G.; Katta, H.Y.; Mojica, A.; Chen, I.-M.A.; Kyrpides, N.C.; Reddy, T. Genomes OnLine database (GOLD) v.7: Updates and new features. Nucleic Acids Res. 2019, 47, D649-D659. [CrossRef]

10. Field, D.; Garrity, G.; Gray, T.; Morrison, N.; Selengut, J.; Sterk, P.; Tatusova, T.; Thomson, N.; Allen, M.J.; Angiuoli, S.V.; et al. The minimum information about a genome sequence (MIGS) specification. Nat. Biotechnol. 2008, 26, 541-547. [CrossRef]

11. Loman, N.J.; Pallen, M.J. Twenty years of bacterial genome sequencing. Nat. Rev. Microbiol. 2015, 13, 787-794. [CrossRef] [PubMed]

12. Land, M.; Hauser, L.; Jun, S.R.; Nookaew, I.; Leuze, M.R.; Ahn, T.H.; Karpinets, T.; Lund, O.; Kora, G.; Wassenaar, T.; et al. Insights from 20 years of bacterial genome sequencing. Funct. Integr. Genom. 2015, 15, 141-161. [CrossRef] [PubMed]

13. Urbieta, M.S.; Donati, E.R.; Chan, K.-G.; Shahar, S.; Sin, L.L.; Goh, K.M. Thermophiles in the genomic era: Biodiversity, science, and applications. Biotechnol. Adv. 2015, 33, 633-647. [CrossRef] [PubMed]

14. Houghton, K.M.; Carere, C.R.; Stott, M.B.; McDonald, I.R. Thermophilic methanotrophs: In hot pursuit. FEMS Microbiol. Ecol. 2019, 95, fiz125. [CrossRef]

15. Lusk, B.G. Thermophiles; or, the modern prometheus: The importance of extreme microorganisms for understanding and applying extracellular electron transfer. Front. Microbiol. 2019, 10, 818. [CrossRef]

16. Karp, P.D.; Ivanova, N.; Krummenacker, M.; Kyrpides, N.; Latendresse, M.; Midford, P.; Ong, W.K.; Paley, S.; Seshadri, R. A comparison of microbial genome web portals. Front. Microbiol. 2019, 10, 208. [CrossRef]

17. Parks, D.H.; Rinke, C.; Chuvochina, M.; Chaumeil, P.A.; Woodcroft, B.J.; Evans, P.N.; Hugenholtz, P.; Tyson, G.W. Recovery of nearly 8,000 metagenome-assembled genomes substantially expands the tree of life. Nat. Microbiol. 2017, 2, 1533-1542. [CrossRef]

18. Alneberg, J.; Karlsson, C.M.G.; Divne, A.M.; Bergin, C.; Homa, F.; Lindh, M.V.; Hugerth, L.W.; Ettema, T.J.G.; Bertilsson, S.; Andersson, A.F.; et al. Genomes from uncultivated prokaryotes: A comparison of metagenome-assembled and single-amplified genomes. Microbiome 2018, 6, 173. [CrossRef]

19. Bowers, R.M.; Kyrpides, N.C.; Stepanauskas, R.; Harmon-Smith, M.; Doud, D.; Reddy, T.B.K.; Schulz, F.; Jarett, J.; Rivers, A.R.; Eloe-Fadrosh, E.A.; et al. Minimum information about a single amplified genome (MISAG) and a metagenome-assembled genome (MIMAG) of bacteria and archaea. Nat. Biotechnol. 2017, 35, 725-731. [CrossRef]

20. Mangot, J.F.; Logares, R.; Sánchez, P.; Latorre, F.; Seeleuthner, Y.; Mondy, S.; Sieracki, M.E.; Jaillon, O.; Wincker, P.; De Vargas, C.; et al. Accessing the genomic information of unculturable oceanic picoeukaryotes by combining multiple single cells. Sci. Rep. 2017, 7, 41498. [CrossRef]

21. Kogawa, M.; Hosokawa, M.; Nishikawa, Y.; Mori, K.; Takeyama, H. Obtaining high-quality draft genomes from uncultured microbes by cleaning and co-assembly of single-cell amplified genomes. Sci. Rep. 2018, 8, 2059. [CrossRef] [PubMed]

22. Yu, F.B.; Blainey, P.C.; Schulz, F.; Woyke, T.; Horowitz, M.A.; Quake, S.R. Microfluidic-based mini-metagenomics enables discovery of novel microbial lineages from complex environmental samples. eLife 2017, 6, e26580. [CrossRef] [PubMed]

23. Berghuis, B.A.; Brian, F.; Schulz, F.; Blainey, P.C.; Woyke, T.; Quake, S.R. Hydrogenotrophic methanogenesis in archaeal phylum Verstraetearchaeota reveals the shared ancestry of all methanogens. Proc. Natl. Acad. Sci. USA 2019, 116, 5037-5044. [CrossRef] [PubMed]

24. Hwang, B.; Lee, J.H.; Bang, D. Single-cell RNA sequencing technologies and bioinformatics pipelines. Exp. Mol. Med. 2018, 50, 96. [CrossRef]

25. Strzelecka, P.M.; Ranzoni, A.M.; Cvejic, A. Dissecting human disease with single-cell omics: Application in model systems and in the clinic. Dis. Model. Mech. 2018, 11, dmm036525. [CrossRef]

26. Zeng, Z.; Miao, N.; Sun, T. Revealing cellular and molecular complexity of the central nervous system using single cell sequencing. Stem Cell Res. Ther. 2018, 9, 234. [CrossRef]

27. Tamura, K.; Stecher, G.; Peterson, D.; Filipski, A.; Kumar, S. MEGA6: Molecular Evolutionary Genetics Analysis version 6.0. Mol. Biol. Evol. 2013, 30, 2725-2729. [CrossRef] 
28. Tahon, G.; Tytgat, B.; Lebbe, L.; Carlier, A.; Willems, A. Abditibacterium utsteinense sp. nov., the first cultivated member of candidate phylum FBP, isolated from ice-free Antarctic soil samples. Syst. Appl. Microbiol. 2018, 41, 279-290. [CrossRef]

29. Waite, D.W.; Vanwonterghem, I.; Rinke, C.; Parks, D.H.; Zhang, Y.; Takai, K.; Sievert, S.M.; Simon, J.; Campbell, B.J.; Hanson, T.E.; et al. Comparative genomic analysis of the class Epsilonproteobacteria and proposed reclassification to Epsilonbacteraeota (phyl. nov.). Front. Microbiol. 2017, 8, 682. [CrossRef]

30. Pande, S.; Kost, C. Bacterial unculturability and the formation of intercellular metabolic networks. Trends Microbiol. 2017, 25, 349-361. [CrossRef]

31. Solden, L.; Lloyd, K.; Wrighton, K. The bright side of microbial dark matter: Lessons learned from the uncultivated majority. Curr. Opin. Microbiol. 2016, 31, 217-226. [CrossRef] [PubMed]

32. Amann, R.I.; Ludwig, W.; Schleifer, K.H. Phylogenetic identification and in situ detection of individual microbial cells without cultivation. Microbiol. Rev. 1995, 59, 143-169. [PubMed]

33. Anantharaman, K.; Brown, C.T.; Hug, L.A.; Sharon, I.; Castelle, C.J.; Probst, A.J.; Thomas, B.C.; Singh, A.; Wilkins, M.J.; Karaoz, U.; et al. Thousands of microbial genomes shed light on interconnected biogeochemical processes in an aquifer system. Nat. Commun. 2016, 7, 13219. [CrossRef] [PubMed]

34. Castelle, C.J.; Banfield, J.F. Major new microbial groups expand diversity and alter our understanding of the tree of life. Cell 2018, 172, 1181-1197. [CrossRef]

35. Youssef, N.H.; Farag, I.F.; Hahn, C.R.; Jarett, J.; Becraft, E.; Eloe-Fadrosh, E.; Lightfoot, J.; Bourgeois, A.; Cole, T.; Ferrante, S.; et al. Genomic characterization of candidate division LCP-89 reveals an atypical cell wall structure, microcompartment production, and dual respiratory and fermentative capacities. Appl. Environ. Microbiol. 2019, 85, e00110-e00119. [CrossRef]

36. De Anda, V.; Zapata-Peñasco, I.; Blaz, J.; Poot-Hernández, A.C.; Contreras-Moreira, B.; González-Laffitte, M.; Gámez-Tamariz, N.; Hernández-Rosales, M.; Eguiarte, L.E.; Souza, V. Understanding the mechanisms behind the response to environmental perturbation in microbial mats: A metagenomic-network based approach. Front. Microbiol. 2018, 9, 2606. [CrossRef]

37. Arrigo, K.R. Marine microorganisms and global nutrient cycles. Nature 2005, 437, 349-355. [CrossRef]

38. Hu, P.; Tom, L.; Singh, A.; Thomas, B.C.; Baker, B.J.; Piceno, Y.M.; Andersen, G.L.; Banfield, J.F. Genome-resolved metagenomic analysis reveals roles for candidate phyla and other microbial community members in biogeochemical transformations in oil reservoirs. MBio 2016, 7. [CrossRef]

39. Hug, L.A.; Baker, B.J.; Anantharaman, K.; Brown, C.T.; Probst, A.J.; Castelle, C.J.; Butterfield, C.N.; Hernsdorf, A.W.; Amano, Y.; Ise, K.; et al. A new view of the tree of life. Nat. Microbiol. 2016, 1, 16048. [CrossRef]

40. Power, J.F.; Carere, C.R.; Lee, C.K.; Wakerley, G.L.J.; Evans, D.W.; Button, M.; White, D.; Climo, M.D.; Hinze, A.M.; Morgan, X.C.; et al. Microbial biogeography of 925 geothermal springs in New Zealand. Nat. Commun. 2018, 9, 2876. [CrossRef]

41. Chan, C.S.; Chan, K.-G.; Ee, R.; Hong, K.-W.; Urbieta, M.S.; Donati, E.R.; Shamsir, M.S.; Goh, K.M. Effects of physiochemical factors on prokaryotic biodiversity in Malaysian circumneutral hot springs. Front. Microbiol. 2017, 8, 1252. [CrossRef] [PubMed]

42. Deng, S.; Ke, T.; Li, L.; Cai, S.; Zhou, Y.; Liu, Y.; Guo, L.; Chen, L.; Zhang, D. Impacts of environmental factors on the whole microbial communities in the rhizosphere of a metal-tolerant plant: Elsholtzia haichowensis Sun. Environ. Pollut. 2018, 237, 1088-1097. [CrossRef] [PubMed]

43. Lladó, S.; López-Mondéjar, R.; Baldrian, P. Drivers of microbial community structure in forest soils. Appl. Microbiol. Biotechnol. 2018, 102, 4331-4338. [CrossRef] [PubMed]

44. Zhang, Y.; Wu, G.; Jiang, H.; Yang, J.; She, W.; Khan, I.; Li, W. Abundant and rare microbial biospheres respond differently to environmental and spatial factors in tibetan hot springs. Front. Microbiol. 2018, 9, 2096. [CrossRef] [PubMed]

45. Morris, J.; Shiller, J.; Mann, R.; Smith, G.; Yen, A.; Rodoni, B. Novel 'Candidatus Liberibacter' species identified in the Australian eggplant psyllid, Acizzia solanicola. Microb. Biotechnol. 2017, 10, 833-844. [CrossRef] [PubMed]

46. Mckenna, B.Y.M. Antibiotics hit the orchard. Nature 2019, 567, 302-303. [CrossRef]

47. Ling, L.L.; Schneider, T.; Peoples, A.J.; Spoering, A.L.; Engels, I.; Conlon, B.P.; Mueller, A.; Schäberle, T.F.; Hughes, D.E.; Epstein, S.; et al. A new antibiotic kills pathogens without detectable resistance. Nature 2015, 517, 455-459. [CrossRef] 
48. Tyson, J.; Elizabeth Sockett, R. Nature knows best: Employing whole microbial strategies to tackle antibiotic resistant pathogens. Environ. Microbiol. Rep. 2017, 9, 47-49. [CrossRef]

49. Tyson, J.; Sockett, R.E. Predatory bacteria: Moving from curiosity towards curative. Trends Microbiol. 2017, 25, 90-91. [CrossRef]

50. Baker, M.; Negus, D.; Raghunathan, D.; Radford, P.; Moore, C.; Clark, G.; Diggle, M.; Tyson, J.; Twycross, J.; Sockett, R.E. Measuring and modelling the response of Klebsiella pneumoniae KPC prey to Bdellovibrio bacteriovorus predation, in human serum and defined buffer. Sci. Rep. 2017, 7, 8329. [CrossRef]

51. Kim, W.C.; Mauborgne, R. Blue ocean strategy. In Harvard Business School Publishing Corporation; Harvard Business Review: Boston, MA, USA, 2004.

52. Castelle, C.J.; Brown, C.T.; Anantharaman, K.; Probst, A.J.; Huang, R.H.; Banfield, J.F. Biosynthetic capacity, metabolic variety and unusual biology in the CPR and DPANN radiations. Nat. Rev. Microbiol. 2018, 16, 629-645. [CrossRef] [PubMed]

53. Makarova, K.S.; Wolf, Y.I.; Koonin, E.V. Towards functional characterization of archaeal genomic dark matter. Biochem. Soc. Trans. 2019, 47, 389-398. [CrossRef] [PubMed]

54. Brown, C.T.; Hug, L.A.; Thomas, B.C.; Sharon, I.; Castelle, C.J.; Singh, A.; Wilkins, M.J.; Wrighton, K.C.; Williams, K.H.; Banfield, J.F. Unusual biology across a group comprising more than $15 \%$ of domain Bacteria. Nature 2015, 523, 208-211. [CrossRef] [PubMed]

55. Dombrowski, N.; Lee, J.H.; Williams, T.A.; Offre, P.; Spang, A. Genomic diversity, lifestyles and evolutionary origins of DPANN archaea. FEMS Microbiol. Lett. 2019, 366, fnz008. [CrossRef] [PubMed]

56. Raina, J.B.; Eme, L.; Pollock, F.J.; Spang, A.; Archibald, J.M.; Williams, T.A. Symbiosis in the microbial world: From ecology to genome evolution. Biol. Open 2018, 7, bio032524. [CrossRef]

57. Tanaka, T.; Kawasaki, K.; Daimon, S.; Kitagawa, W.; Yamamoto, K.; Tamaki, H.; Tanaka, M.; Nakatsu, C.H.; Kamagata, Y. A hidden pitfall in the preparation of agar media undermines microorganism cultivability. Appl. Environ. Microbiol. 2014, 80, 7659-7666. [CrossRef]

58. Aanderud, Z.T.; Jones, S.E.; Fierer, N.; Lennon, J.T. Resuscitation of the rare biosphere contributes to pulses of ecosystem activity. Front. Microbiol. 2015, 6, 24. [CrossRef]

59. Tighe, S.; Afshinnekoo, E.; Rock, T.M.; McGrath, K.; Alexander, N.; McIntyre, A.; Ahsanuddin, S.; Bezdan, D.; Green, S.J.; Joye, S.; et al. Genomic methods and microbiological technologies for profiling novel and extreme environments for the extreme microbiome project (XMP). J. Biomol. Tech. JBT 2017, 28, 31-39. [CrossRef]

60. Merino, N.; Aronson, H.S.; Bojanova, D.; Feyhl-buska, J.; Michael, L.; Zhang, S.; Giovannelli, D. Living at the extremes: Extremophiles and the limits of life in a planetary context. Front. Microbiol. 2019, 10, 780. [CrossRef]

61. Lodhi, A.F.; Zhang, Y.; Adil, M.; Deng, Y. Antibiotic discovery: Combining isolation chip (ichip) technology and co-culture technique. Appl. Microbiol. Biotechnol. 2018, 102, 7333-7341. [CrossRef]

62. Belanger, A.; Lewis, K.; Epstein, S.S.; Nichols, D.; Kanigan, T.; Pham, L.; Mehta, A.; Trakhtenberg, E.M.; Cahoon, N. Use of ichip for high-throughput in situ cultivation of "uncultivable" microbial species. Appl. Environ. Microbiol. 2010, 76, 2445-2450.

63. Chaudhary, D.K.; Khulan, A.; Kim, J. Development of a novel cultivation technique for uncultured soil bacteria. Sci. Rep. 2019, 9, 6666. [CrossRef] [PubMed]

64. Sun, Y.; Liu, Y.; Pan, J.; Wang, F.; Li, M. Perspectives on cultivation strategies of Archaea. Microb. Ecol. 2019, 1-15. [CrossRef] [PubMed]

65. Jiang, Z.; Yuan, C.G.; Xiao, M.; Tian, X.P.; Khan, I.U.; Kim, C.J.; Zhi, X.Y.; Li, W.J. Abyssicoccus albus gen. nov., sp. nov., a novel member of the family Staphylococcaceae isolated from marine sediment of the Indian Ocean. Antonie Van Leeuwenhoek 2016, 109, 1153-1160. [CrossRef] [PubMed]

66. Pukall, R.; Schumann, P.; Schütte, C.; Gols, R.; Dicke, M. Acaricomes phytoseiuli gen. nov., sp. nov., isolated from the predatory mite Phytoseiulus persimilis. Int. J. Syst. Evol. Microbiol. 2006, 56, 465-469. [CrossRef]

67. Chen, S.; Dong, X. Acetanaero bacterium elongatum gen. nov., sp. nov., from paper mill waste water. Int. J. Syst. Evol. Microbiol. 2004, 54, 2257-2262. [CrossRef] [PubMed]

68. Pfeiffer, N.; Desmarchelier, C.; Blaut, M.; Daniel, H.; Haller, D.; Clavel, T. Acetatifactor muris gen. nov., sp. nov., a novel bacterium isolated from the intestine of an obese mouse. Arch. Microbiol. 2012, 194, 901-907. [CrossRef] 
69. Johnson, D.B.; Stallwood, B.; Kimura, S.; Hallberg, K.B. Isolation and characterization of Acidicaldus organivorus, gen. nov., sp. nov.: A novel sulfur-oxidizing, ferric iron-reducing thermo-acidophilic heterotrophic Proteo bacterium. Arch. Microbiol. 2006, 185, 212-221. [CrossRef]

70. Itoh, T.; Yamanoi, K.; Kudo, T.; Ohkuma, M.; Takashina, T. Aciditerrimonas ferrireducens gen. nov., sp. nov., an iron-reducing thermoacidophilic actinobacterium isolated from a solfataric field. Int. J. Syst. Evol. Microbiol. 2011, 61, 1281-1285. [CrossRef]

71. Yamada, T.; Imachi, H.; Ohashi, A.; Harada, H.; Hanada, S.; Kamagata, Y.; Sekiguchi, Y. Bellilinea caldifistulae gen. nov., sp. nov and Longilinea arvoryzae gen. nov., sp. nov., strictly anaerobic, filamentous bacteria of the phylum Chloroflexi isolated from methanogenic propionate-degrading consortia. Int. J. Syst. Evol. Microbiol. 2007, 57, 2299-2306. [CrossRef]

72. Tsuruoka, N.; Tsujimoto, Y.; Ishihara, D.; Kimura, N.; Nishino, T.; Saito, R.; Sahara, T.; Furuya, H.; Watanabe, K.; Shigeri, Y. Caenibacillus caldisaponilyticus gen. nov., sp. nov., a thermophilic, spore-forming and phospholipid-degrading bacterium isolated from acidulocompost. Int. J. Syst. Evol. Microbiol. 2016, 66, 2684-2690.

73. Wagner, I.D.; Ahmed, S.; Zhao, W.; Zhang, C.L.; Romanek, C.S.; Rohde, M.; Wiegel, J. Caldanaerovirga acetigignens gen. nov., sp. nov., an anaerobic xylanolytic, alkalithermophilic bacterium isolated from Trego Hot Spring, Nevada, USA. Int. J. Syst. Evol. Microbiol. 2009, 59, 2685-2691. [CrossRef] [PubMed]

74. Sorokin, D.Y.; Rakitin, A.L.; Gumerov, V.M.; Beletsky, A.V.; Sinninghe Damsté, J.S.; Mardanov, A.V.; Ravin, N.V. Phenotypic and genomic properties of Chitinispirillum alkaliphilum gen. nov., sp. nov., a haloalkaliphilic anaerobic chitinolytic bacterium representing a novel class in the phylum Fibrobacteres. Front. Microbiol. 2016, 7, 407. [CrossRef] [PubMed]

75. Hirsch, P.; Hoffmann, B. Dichotomicrobium thermohalophilum, gen. nov., spec, nov., budding prosthecate bacteria from the solar lake (Sinai) and some related strains. Syst. Appl. Microbiol. 1989, 149, 547-556. [CrossRef]

76. Labeda, D.P.; Kroppenstedt, R.M.; Euzéby, J.P.; Tindall, B.J. Proposal of Goodfellowiella gen. nov. to replace the illegitimate genus name Goodfellowia labeda and Kroppenstedt 2006. Int. J. Syst. Evol. Microbiol. 2008, 58, 1047-1048. [CrossRef] [PubMed]

77. Kim, J.M.; Jung, J.Y.; Chae, H.B.; Park, W.; Jeon, C.O. Hwanghaeicola aestuarii gen. nov., sp. nov., a moderately halophilic bacterium isolated from a tidal flat of the Yellow Sea. Int. J. Syst. Evol. Microbiol. 2010, 60, 2877-2881. [CrossRef]

78. Zhang, C.F.; Ai, M.J.; Wang, J.X.; Liu, S.W.; Zhao, L.L.; Su, J.; Sun, C.H.; Yu, L.Y.; Zhang, Y.Q. Herbihabitans rhizosphaerae gen. nov., sp. nov., a member of the family Pseudonocardiaceae isolated from rhizosphere soil of the herb Limonium sinense (Girard). Int. J. Syst. Evol. Microbiol. 2016, 66, 4156-4161.

79. Rekha, P.D.; Young, C.C.; Kämpfer, P.; Martin, K.; Arun, A.B.; Chen, W.M.; Lai, W.A.; Chao, J.H.; Shen, F.T. Jhaorihella thermophila gen. nov., sp. nov., a moderately thermophilic bacterium isolated from a coastal hot spring. Int. J. Syst. Evol. Microbiol. 2011, 61, 1544-1548. [CrossRef]

80. Jumas-Bilak, E.; Carlier, J.P.; Jean-Pierre, H.; Citron, D.; Bernard, K.; Damay, A.; Gay, B.; Teyssier, C.; Campos, J.; Marchandin, H. Jonquetella anthropi gen. nov., sp. nov., the first member of the candidate phylum "Synergistetes" isolated from man. Int. J. Syst. Evol. Microbiol. 2007, 57, 2743-2748. [CrossRef]

81. Ara, I.; Kudo, T. Krasilnikovia gen. nov., a new member of the family Micromonosporaceae and description of Krasilnikovia cinnamonea sp. nov. Actinomycetologica 2007, 21, 1-10. [CrossRef]

82. Weon, H.Y.; Kim, B.Y.; Kwon, S.W.; Park, I.C.; Cha, I.B.; Tindall, B.J.; Stackebrandt, E.; Trüper, H.G.; Go, S.J. Leadbetterella byssophila gen. nov., sp. nov., isolated from cotton-waste composts for the cultivation of oyster mushroom. Int. J. Syst. Evol. Microbiol. 2005, 55, 2297-2302. [CrossRef] [PubMed]

83. Yu, Z.; Cao, Y.; Zhou, G.; Yin, J.; Qiu, J. Mangrovicoccus ximenensis gen. nov., sp. nov., isolated from mangrove forest sediment. Int. J. Syst. Evol. Microbiol. 2018, 68, 2172-2177. [CrossRef] [PubMed]

84. Vorobev, A.V.; Baani, M.; Doronina, N.V.; Brady, A.L.; Liesack, W.; Dunfield, P.F.; Dedysh, S.N. Methyloferula stellata gen. nov., sp. nov., an acidophilic, obligately methanotrophic bacterium that possesses only a soluble methane monooxygenase. Int. J. Syst. Evol. Microbiol. 2011, 61, 2456-2463. [CrossRef] [PubMed]

85. Chernikova, T.N.; Dallimore, J.; Lünsdorf, H.; Heipieper, H.J.; Golyshin, P.N. Monaibacterium marinum, gen. nov, sp. nov, a new member of the Alphaproteo bacteria isolated from seawater of Menai Straits, Wales, UK. Int. J. Syst. Evol. Microbiol. 2017, 67, 3310-3317. [PubMed] 
86. Zhang, L.; Shen, X.; Liu, Y.; Li, S. Nafulsella turpanensis gen. nov., sp. nov., a member of the phylum Bacteroidetes isolated from soil. Int. J. Syst. Evol. Microbiol. 2013, 63, 1639-1645. [CrossRef] [PubMed]

87. Asker, D.; Beppu, T.; Ueda, K. Nubsella zeaxanthinifaciens gen. nov., sp. nov., a zeaxanthin-producing bacterium of the family Sphingobacteriaceae isolated from freshwater. Int. J. Syst. Evol. Microbiol. 2008, 58, 601-606. [CrossRef]

88. Podosokorskaya, O.A.; Bonch-Osmolovskaya, E.A.; Novikov, A.A.; Kolganova, T.V.; Kublanov, I.V. Ornatilinea apprima gen. nov., sp. nov., a cellulolytic representative of the class Anaerolineae. Int. J. Syst. Evol. Microbiol. 2013, 63, 86-92. [CrossRef]

89. Bengelsdorf, F.R.; Poehlein, A.; Schiel-Bengelsdorf, B.; Daniel, R.; Dürre, P. Genome sequence of the acetogenic bacterium Oxobacter pfennigii DSM 3222 ${ }^{\mathrm{T}}$. Genome Announc. 2015, 3, e01408-e01415. [CrossRef]

90. Xia, X.; Wu, S.; Han, Y.; Liao, S.; Wang, G. Pelobium manganitolerans gen. nov., sp. nov., isolated from sludge of a manganese mine. Int. J. Syst. Evol. Microbiol. 2016, 66, 4954-4959.

91. Kulichevskaya, I.S.; Ivanova, A.O.; Belova, S.E.; Baulina, O.I.; Bodelier, P.L.E.; Rijpstra, W.I.C.; Sinninghe Damsté, J.S.; Zavarzin, G.A.; Dedysh, S.N. Schlesneria paludicola gen. nov., sp. nov., the first acidophilic member of the order Planctomycetales, from Sphagnum-dominated boreal wetlands. Int. J. Syst. Evol. Microbiol. 2007, 57, 2680-2687. [CrossRef]

92. Konstantinidis, K.T.; Rossello-Mora, R.; Amann, R. Moving the cataloguing of the "uncultivated majority" forward. Syst. Appl. Microbiol. 2019, 42, 3-4. [CrossRef] [PubMed]

93. Danczak, R.E.; Johnston, M.D.; Kenah, C.; Slattery, M.; Wrighton, K.C.; Wilkins, M.J. Members of the Candidate Phyla Radiation are functionally differentiated by carbon- and nitrogen-cycling capabilities. Microbiome 2017, 5, 112. [CrossRef] [PubMed]

94. Wang, Y.; Huang, Z.; Goh, K.M.; Evans, P.N.; Liu, L.; Mao, Y.; Hugenholtz, P.; Tyson, G.W.; Li, W.; Zhang, T. Further expansion of methane metabolism in the Archaea. bioRxiv 2018. [CrossRef]

95. Kadnikov, V.V.; Mardanov, A.V.; Beletsky, A.V.; Rakitin, A.L.; Frank, Y.A.; Karnachuk, O.V.; Ravin, N.V. Phylogeny and physiology of candidate phylum BRC1 inferred from the first complete metagenome-assembled genome obtained from deep subsurface aquifer. Syst. Appl. Microbiol. 2019, 42, 67-76. [CrossRef] [PubMed]

96. Quince, C.; Walker, A.W.; Simpson, J.T.; Loman, N.J.; Segata, N. Shotgun metagenomics, from sampling to analysis. Nat. Biotechnol. 2017, 35, 833-844. [CrossRef] [PubMed]

97. Parks, D.H.; Imelfort, M.; Skennerton, C.T.; Hugenholtz, P.; Tyson, G.W. CheckM: Assessing the quality of microbial genomes recovered from isolates, single cells, and metagenomes. Genome Res. 2015, 25, 1043-1055. [CrossRef]

98. Wilkins, L.G.E.; Ettinger, C.L.; Jospin, G.; Eisen, J.A. Metagenome-assembled genomes provide new insight into the microbial diversity of two thermal pools in Kamchatka, Russia. Sci. Rep. 2019, 9, 3059. [CrossRef]

99. Dong, X.; Greening, C.; Rattray, J.E.; Chakraborty, A.; Chuvochina, M.; Mayumi, D.; Dolfing, J.; Li, C.; Brooks, J.M.; Bernard, B.B.; et al. Metabolic potential of uncultured bacteria and archaea associated with petroleum seepage in deep-sea sediments. Nat. Commun. 2019, 10, 1816. [CrossRef]

100. Kasanke, C.P.; Collins, R.E.; Leigh, M.B. Identification and characterization of a dominant sulfolane-degrading Rhodoferax sp. via stable isotope probing combined with metagenomics. Sci. Rep. 2019, 9, 3121. [CrossRef]

101. Sharp, C.; Kleiner, M.; Gordon, P.M.K.; Pon, R.T.; Dong, X. A shared core microbiome in soda lakes separated by large distances. Nat. Commun. 2019, 10, 4230.

102. Wang, Y.; Niu, Q.; Zhang, X.; Liu, L.; Wang, Y.; Chen, Y.; Negi, M.; Figeys, D.; Li, Y.-Y.; Zhang, T. Exploring the effects of operational mode and microbial interactions on bacterial community assembly in a one-stage partial-nitritation anammox reactor using integrated multi-omics. Microbiome 2019, 7, 122. [CrossRef] [PubMed]

103. Tan, S.; Liu, J.; Fang, Y.; Hedlund, B.P.; Lian, Z.H.; Huang, L.Y.; Li, J.T.; Huang, L.N.; Li, W.J.; Jiang, H.C.; et al. Insights into ecological role of a new deltaproteobacterial order Candidatus Acidulodesulfobacterales by metagenomics and metatranscriptomics. ISME J. 2019, 13, 2044-2057. [CrossRef] [PubMed]

104. Tsementzi, D.; Rodriguez-R, L.M.; Ruiz-Perez, C.A.; Meziti, A.; Hatt, J.K.; Konstantinidis, K.T. Ecogenomic characterization of widespread, closely-related SAR11 clades of the freshwater genus "Candidatus Fonsibacter" and proposal of Ca. Fonsibacter lacus sp. nov. Syst. Appl. Microbiol. 2019, 42, 495-505. [CrossRef] 
105. Castelle, C.J.; Brown, C.T.; Thomas, B.C.; Williams, K.H.; Banfield, J.F. Unusual respiratory capacity and nitrogen metabolism in a Parcubacterium (OD1) of the Candidate Phyla Radiation. Sci. Rep. 2017, 7, 40101. [CrossRef] [PubMed]

106. Kadnikov, V.V.; Mardanov, A.V.; Beletsky, A.V.; Karnachuk, O.V.; Ravin, N.V. Genome of the candidate phylum Aminicenantes bacterium from a deep subsurface thermal aquifer revealed its fermentative saccharolytic lifestyle. Extremophiles 2019, 23, 189-200. [CrossRef] [PubMed]

107. Tully, B.J.; Graham, E.D.; Heidelberg, J.F. The reconstruction of 2,631 draft metagenome-assembled genomes from the global oceans. Sci. Data 2018, 5, 170203. [CrossRef] [PubMed]

108. Wong, H.L.; White, R.A.; Visscher, P.T.; Charlesworth, J.C.; Vázquez-Campos, X.; Burns, B.P. Disentangling the drivers of functional complexity at the metagenomic level in Shark Bay microbial mat microbiomes. ISME J. 2018, 12, 2619-2639. [CrossRef] [PubMed]

109. Alcorta, J.; Espinoza, S.; Viver, T.; Alcamán-Arias, M.E.; Trefault, N.; Rosselló-Móra, R.; Díez, B. Temperature modulates Fischerella thermalis ecotypes in Porcelana Hot Spring. Syst. Appl. Microbiol. 2018, 41, 531-543. [CrossRef]

110. Fortney, N.W.; He, S.; Converse, B.J.; Boyd, E.S.; Roden, E.E. Investigating the composition and metabolic potential of microbial communities in chocolate pots hot springs. Front. Microbiol. 2018, 9, 2075. [CrossRef]

111. Press, M.O.; Roehe, R.; Snelling, T.J.; Dewhurst, R.J.; Watson, M.; Stewart, R.D.; Auffret, M.D.; Warr, A.; Langford, K.W.; Liachko, I.; et al. Assembly of 913 microbial genomes from metagenomic sequencing of the cow rumen. Nat. Commun. 2018, 9, 870.

112. Hugerth, L.W.; Larsson, J.; Alneberg, J.; Lindh, M.V.; Legrand, C.; Pinhassi, J.; Andersson, A.F. Metagenome-assembled genomes uncover a global brackish microbiome. Genome Biol. 2015, 16, 279. [CrossRef] [PubMed]

113. Li, J.; Dasgupta, S.; Guo, Z.; Chen, S.; Xu, H.; Ta, K.; Bai, S.; Du, M.; Peng, X.; Chen, M. Microplastics contaminate the deepest part of the world's ocean. Geochemical Perspect. Lett. 2018, 9, 1-5.

114. Wei, R.; Zimmermann, W. Microbial enzymes for the recycling of recalcitrant petroleum-based plastics: How far are we? Microb. Biotechnol. 2017, 10, 1308-1322. [CrossRef] [PubMed]

115. Oberbeckmann, S.; Labrenz, M. Marine microbial assemblages on microplastics: Diversity, adaptation, and role in degradation. Ann. Rev. Mar. Sci. 2019, 12. [CrossRef] [PubMed]

116. Yoshida, S.; Hiraga, K.; Takehana, T.; Taniguchi, I.; Yamaji, H.; Maeda, Y.; Toyohara, K.; Miyamoto, K.; Kimura, Y.; Oda, K. A bacterium that degrades and assimilates poly(ethylene terephthalate). Science 2016, 351, 1196-1199. [CrossRef] [PubMed]

117. Skaf, M.S.; Austin, H.P.; Crowley, M.F.; McGeehan, J.E.; Silveira, R.L.; Donohoe, B.S.; Pollard, B.C.; Michener, W.E.; Kearns, F.L.; Duman, R.; et al. Characterization and engineering of a plastic-degrading aromatic polyesterase. Proc. Natl. Acad. Sci. USA 2018, 115, E4350-E4357.

118. Joo, S.; Seo, H.; Cho, I.J.; Lee, S.Y.; Choi, S.Y.; Son, H.F.; Shin, T.J.; Sagong, H.-Y.; Kim, K.-J. Structural insight into molecular mechanism of poly(ethylene terephthalate) degradation. Nat. Commun. 2018, 9, 382. [CrossRef]

119. Wei, R.; Föllner, C.; Then, J.; Zimmermann, W.; Sträter, N.; Roth, C.; Oeser, T. Structural and functional studies on a thermostable polyethylene terephthalate degrading hydrolase from Thermobifida fusca. Appl. Microbiol. Biotechnol. 2014, 98, 7815-7823.

120. Zhang, Y.; Wang, L.; Chen, J.; Wu, J. Enhanced activity toward PET by site-directed mutagenesis of Thermobifida fusca cutinase-CBM fusion protein. Carbohydr. Polym. 2013, 97, 124-129. [CrossRef]

121. Danso, D.; Schmeisser, C.; Chow, J.; Zimmermann, W.; Wei, R.; Leggewie, C.; Li, X.; Hazen, T.; Streita, W.R. New insights into the function and gobal distribution of polyethylene terephthalate (PET)-degrading cacteria and enzymes in marine and terrestrial metagenomes. Appl. Environ. Microbiol. 2018, 53, 1689-1699.

122. Baltz, R.H. Gifted microbes for genome mining and natural product discovery. J. Ind. Microbiol. Biotechnol. 2017, 44, 573-588. [CrossRef] [PubMed]

123. Idris, H.; Goodfellow, M.; Sanderson, R.; Asenjo, J.A.; Bull, A.T. Actinobacterial rare biospheres and dark matter revealed in habitats of the Chilean Atacama desert. Sci. Rep. 2017, 7, 8373. [CrossRef] [PubMed]

124. Lambrechts, S.; Willems, A.; Tahon, G. Uncovering the uncultivated majority in Antarctic soils: Toward a synergistic approach. Front. Microbiol. 2019, 10, 242. [CrossRef] [PubMed]

125. Cavicchioli, R.; Charlton, T.; Ertan, H.; Omar, S.M.; Siddiqui, K.S.; Williams, T.J. Biotechnological uses of enzymes from psychrophiles. Microb. Biotechnol. 2011, 4, 449-460. [CrossRef] [PubMed] 
126. Pikuta, E.V.; Menes, R.J.; Bruce, A.M.; Lyu, Z.; Patel, N.B.; Liu, Y.; Hoover, R.B.; Busse, H.J.; Lawson, P.A.; Whitman, W.B. Raineyella antarctica gen. nov., sp. nov., a psychrotolerant, D-amino-acid-utilizing anaerobe isolated from two geographic locations of the Southern Hemisphere. Int. J. Syst. Evol. Microbiol. 2016, 66, 5529-5536. [PubMed]

127. Sheridan, P.P.; Loveland-Curtze, J.; Miteva, V.I.; Brenchley, J.E. Rhodoglobus vestalii gen. nov., sp. nov., a novel psychrophilic organism isolated from an Antarctic Dry Valley Lake. Int. J. Syst. Evol. Microbiol. 2003, 53, 985-994. [CrossRef]

128. Li, H.R.; Yu, Y.; Luo, W.; Zeng, Y.X. Marisediminicola antarctica gen. nov., sp. nov., an Actinobacterium isolated from the Antarctic. Int. J. Syst. Evol. Microbiol. 2010, 60, 2535-2539. [CrossRef]

129. Podosokorskaya, O.A.; Kadnikov, V.V.; Gavrilov, S.N.; Mardanov, A.V.; Merkel, A.Y.; Karnachuk, O.V.; Ravin, N.V.; Bonch-Osmolovskaya, E.A.; Kublanov, I.V. Characterization of Melioribacter roseus gen. nov., sp. nov., a novel facultatively anaerobic thermophilic cellulolytic bacterium from the class Ignavibacteria, and a proposal of a novel bacterial phylum Ignavibacteriae. Environ. Microbiol. 2013, 15, 1759-1771. [CrossRef]

130. Rakitin, A.L.; Ermakova, A.Y.; Ravin, N.V. Novel endoxylanases of the moderately thermophilic polysaccharide-degrading bacterium Melioribacter roseus. J. Microbiol. Biotechnol. 2015, 25, 1476-1484. [CrossRef]

131. Mardanov, A.V.; Bonch-Osmolovskaya, E.A.; Gavrilov, S.N.; Ravin, N.V.; Podosokorskaya, O.A.; Kadnikov, V.V.; Beletsky, A.V.; Kublanov, I.V. Genomic analysis of Melioribacter roseus, facultatively anaerobic organotrophic bacterium representing a novel deep lineage within Bacteriodetes/Chlorobi group. PLoS ONE 2013, 8, e53047.

132. Hameed, A.; Shahina, M.; Lin, S.Y.; Sridhar, K.R.; Young, L.S.; Lee, M.R.; Chen, W.M.; Chou, J.H.; Young, C.C. Siansivirga zeaxanthinifaciens gen. nov., sp. nov., a novel zeaxanthin-producing member of the family Flavobacteriaceae isolated from coastal seawater of Taiwan. FEMS Microbiol. Lett. 2012, 333, 37-45. [CrossRef] [PubMed]

133. Hameed, A.; Shahina, M.; Huang, H.C.; Lai, W.A.; Lin, S.Y.; Stothard, P.; Young, C.C. Complete genome sequence of Siansivirga zeaxanthinifaciens CC-SAMT-1T, a flavobacterium isolated from coastal surface seawater. Mar. Genomics 2018, 37, 21-25. [CrossRef]

134. Liao, Z.; Holtzapple, M.; Yan, Y.; Wang, H.; Li, J.; Zhao, B. Insights into xylan degradation and haloalkaline adaptation through whole-genome analysis of Alkalitalea saponilacus, an anaerobic haloalkaliphilic bacterium capable of secreting novel halostable xylanase. Genes 2019, 10, 1. [CrossRef] [PubMed]

135. Zhao, B.; Chen, S. Alkalitalea saponilacus gen. nov., sp. nov., an obligately anaerobic, alkaliphilic, xylanolytic bacterium from a meromictic soda lake. Int. J. Syst. Evol. Microbiol. 2012, 62, 2618-2623. [CrossRef] [PubMed]

136. Yaakop, A.S.; Chan, K.-G.; Ee, R.; Lim, Y.L.; Lee, S.-K.; Manan, F.A.; Goh, K.M. Characterization of the mechanism of prolonged adaptation to osmotic stress of Jeotgalibacillus malaysiensis via genome and transcriptome sequencing analyses. Sci. Rep. 2016, 6, 33660. [CrossRef]

137. Liew, K.J.; Lim, L.; Woo, H.Y.; Chan, K.G.; Shamsir, M.S.; Goh, K.M. Purification and characterization of a novel GH1 beta-glucosidase from Jeotgalibacillus malaysiensis. Int. J. Biol. Macromol. 2018, 115, 1094-1102. [CrossRef]

138. Gomes, J.; Gomes, I.; Terler, K.; Gubala, N.; Ditzelmüller, G.; Steiner, W. Optimisation of culture medium and conditions for $\alpha$-L-arabinofuranosidase production by the extreme thermophilic eubacterium Rhodothermus marinus. Enzyme Microb. Technol. 2000, 27, 414-422. [CrossRef]

139. Hachem, M.A.; Karlsson, E.N.; Bartonek-Roxâ, E.; Raghothama, S.; Simpson, P.J.; Gilbert, H.J.; Williamson, M.P.; Holst, O. Carbohydrate-binding modules from a thermostable Rhodothermus marinus xylanase: Cloning, expression and binding studies. Biochem. J. 2000, 345, 53-60. [CrossRef]

140. Park, M.-J.; Oh, J.H.; Yang, S.-H.; Kwon, K.K. Roseithermus sacchariphilus gen. nov., sp. nov. and proposal of Salisaetaceae fam. nov., representing new family in the order Rhodothermales. Int. J. Syst. Evol. Microbiol. 2019, 69, 1213-1219. [CrossRef]

141. Liew, K.-J.; Teo, S.C.; Shamsir, M.S.; Sani, R.K.; Chong, C.S.; Chan, K.G.; Goh, K.M. Complete genome sequence of Rhodothermaceae bacterium RA with cellulolytic and xylanolytic activities. 3 Biotech 2018, 8, 376. [CrossRef]

142. Goh, K.M.; Chan, K.-G.; Lim, S.W.; Liew, K.J.; Chan, C.S.; Shamsir, M.S.; Ee, R.; Adrian, T.-G.-S. Genome analysis of a new Rhodothermaceae strain isolated from a hot spring. Front. Microbiol. 2016, 7, 1109. [CrossRef] [PubMed] 
143. Jun, K.; Yi, C.; Shahir, M.; Kumar, R.; Shiong, C.; Mau, K. Heterologous expression, purification and biochemical characterization of a new endo-1, 4- $\beta$-xylanase from Rhodothermaceae RA bacterium RA. Protein Expr. Purif. 2019, 164, 105464.

144. Teo, S.C.; Liew, K.J.; Shamsir, M.S.; Chong, C.S.; Bruce, N.C.; Chan, K.-G.; Goh, K.M. Characterizing a halo-tolerant GH10 xylanase from Roseithermus sacchariphilus strain RA and its CBM-truncated variant. Int. J. Mol. Sci. 2019, 20, E2284. [CrossRef] [PubMed]

145. Izumori, K. Izumoring: A strategy for bioproduction of all hexoses. J. Biotechnol. 2006, 124, 717-722. [CrossRef] [PubMed]

146. Chattopadhyay, S.; Raychaudhuri, U.; Chakraborty, R. Artificial sweeteners-A review. J. Food Sci. Technol. 2014, 51, 611-621. [CrossRef]

147. Wasaki, J.; Taguchi, H.; Senoura, T.; Akasaka, H.; Watanabe, J.; Kawaguchi, K.; Komata, Y.; Hanashiro, K.; Ito, S. Identification and distribution of cellobiose 2-epimerase genes by a PCR-based metagenomic approach. Appl. Microbiol. Biotechnol. 2015, 99, 4287-4295. [CrossRef]

148. Pimentel, A.C.; Ematsu, G.C.G.; Liberato, M.V.; Paixão, D.A.A.; Franco Cairo, J.P.L.; Mandelli, F.; Tramontina, R.; Gandin, C.A.; de Oliveira Neto, M.; Squina, F.M.; et al. Biochemical and biophysical properties of a metagenome-derived GH5 endoglucanase displaying an unconventional domain architecture. Int. J. Biol. Macromol. 2017, 99, 384-393. [CrossRef]

149. Kotik, M.; Vanacek, P.; Kunka, A.; Prokop, Z.; Damborsky, J. Metagenome-derived haloalkane dehalogenases with novel catalytic properties. Appl. Microbiol. Biotechnol. 2017, 101, 6385-6397. [CrossRef]

150. Rong, Z.; Cui, H.-L.; Huo, Y.-Y.; Xu, X.-W.; Jian, S.-L.; Cheng, H. Two novel deep-sea sediment metagenome-derived esterases: Residue 199 is the determinant of substrate specificity and preference. Microb. Cell Factories 2018, 17, 16.

151. Angelov, A.; Pham, V.T.T.; Übelacker, M.; Brady, S.; Leis, B.; Pill, N.; Brolle, J.; Mechelke, M.; Moerch, M.; Henrissat, B.; et al. A metagenome-derived thermostable $\beta$-glucanase with an unusual module architecture which defines the new glycoside hydrolase family GH148. Sci. Rep. 2017, 7, 17306. [CrossRef]

152. Tao, L.Y.; Gong, J.S.; Su, C.; Jiang, M.; Li, H.; Li, H.; Lu, Z.M.; Xu, Z.H.; Shi, J.S. Mining and expression of a metagenome-derived keratinase responsible for biosynthesis of silver nanoparticles. ACS Biomater. Sci. Eng. 2018, 4, 1307-1315. [CrossRef]

153. Silva-Portela, R.C.B.; Carvalho, F.M.; Pereira, C.P.M.; De Souza-Pinto, N.C.; Modesti, M.; Fuchs, R.P.; Agnez-Lima, L.F. ExoMeg1: A new exonuclease from metagenomic library. Sci. Rep. 2016, 6, 19712. [CrossRef] [PubMed]

154. Toyama, D.; de Morais, M.A.B.; Ramos, F.C.; Zanphorlin, L.M.; Tonoli, C.C.C.; Balula, A.F.; de Miranda, F.P.; Almeida, V.M.; Marana, S.R.; Ruller, R.; et al. A novel $\beta$-glucosidase isolated from the microbial metagenome of Lake Poraquê (Amazon, Brazil). Biochim. Biophys. Acta—Proteins Proteom. 2018, 1866, 569-579. [CrossRef] [PubMed]

155. Berini, F.; Casciello, C.; Marcone, G.L.; Marinelli, F. Metagenomics: Novel enzymes from non-culturable microbes. FEMS Microbiol. Lett. 2017, 364, fnx211. [CrossRef]

156. Tiwari, R.; Nain, L.; Labrou, N.E.; Shukla, P. Bioprospecting of functional cellulases from metagenome for second generation biofuel production: A review. Crit. Rev. Microbiol. 2018, 44, 244-257. [CrossRef]

157. Garza, D.R.; Dutilh, B.E. From cultured to uncultured genome sequences: Metagenomics and modeling microbial ecosystems. Cell. Mol. Life Sci. 2015, 72, 4287-4308. [CrossRef]

158. Hedlund, B.P.; Dodsworth, J.A.; Murugapiran, S.K.; Rinke, C.; Woyke, T. Impact of single-cell genomics and metagenomics on the emerging view of extremophile "microbial dark matter". Extremophiles 2014, 18, 865-875. [CrossRef]

159. Mende, D.R.; Aylward, F.O.; Eppley, J.M.; Nielsen, T.N.; DeLong, E.F. Improved environmental genomes via integration of metagenomic and single-cell assemblies. Front. Microbiol. 2016, 7, 143. [CrossRef]

160. Berdy, B.; Spoering, A.L.; Ling, L.L.; Epstein, S.S. In situ cultivation of previously uncultivable microorganisms using the ichip. Nat. Protoc. 2017, 12, 2232-2242. [CrossRef]

161. Han, K.; Li, Z.F.; Peng, R.; Zhu, L.P.; Zhou, T.; Wang, L.G.; Li, S.G.; Zhang, X.B.; Hu, W.; Wu, Z.H.; et al. Extraordinary expansion of a Sorangium cellulosum genome from an alkaline milieu. Sci. Rep. 2013, 3, 2101. [CrossRef] 
162. Riley, A.B.; Kim, D.; Hansen, A.K. Genome sequence of "Candidatus Carsonella ruddii" strain BC, a nutritional endosymbiont of Bactericera cockerelli. Genome Announc. 2017, 5, e00236-17. [CrossRef] [PubMed]

163. Yoon, S.H.; Ha, S.M.; Kwon, S.; Lim, J.; Kim, Y.; Seo, H.; Chun, J. Introducing EzBioCloud: A taxonomically united database of 16S rRNA gene sequences and whole-genome assemblies. Int. J. Syst. Evol. Microbiol. 2017, 67, 1613-1617. [PubMed]

164. Goh, K.M.; Gan, H.M.; Chan, K.-G.; Chan, G.F.; Shahar, S.; Chong, C.S.; Kahar, U.M.; Chai, K.P. Analysis of Anoxybacillus genomes from the aspects of lifestyle adaptations, prophage diversity, and carbohydrate metabolism. PLoS ONE 2014, 9, e90549. [CrossRef] [PubMed]

165. Saw, J.H.; Mountain, B.W.; Feng, L.; Omelchenko, M.V.; Hou, S.; Saito, J.A.; Stott, M.B.; Li, D.; Zhao, G.; $\mathrm{Wu}, \mathrm{J}$; et al. Encapsulated in silica: Genome, proteome and physiology of the thermophilic bacterium Anoxybacillus flavithermus WK1. Genome Biol. 2008, 9, R161. [CrossRef] [PubMed]

166. Chowdhary, N.; Selvaraj, A.; Kumaar, L.K.; Kumar, G.R. Genome wide re-annotation of Caldicellulosiruptor saccharolyticus with new insights into genes involved in biomass degradation and hydrogen production. PLoS ONE 2015, 10, e0133183. [CrossRef] [PubMed]

167. Maeder, D.L.; Weiss, R.B.; Dunn, D.M.; Cherry, J.L.; González, J.M.; DiRuggiero, J.; Robb, F.T. Divergence of the hyperthermophilic archaea Pyrococcus furiosus and P. horikoshii inferred from complete genomic sequences. Genetics 1999, 152, 1299-1305. [PubMed]

168. Da Costa, W.L.O.; De Aragão Araújo, C.L.; Dias, L.M.; De Sousa Pereira, L.C.; Alves, J.T.C.; Araújo, F.A.; Folador, E.L.; Henriques, I.; Silva, A.; Folador, A.R.C. Functional annotation of hypothetical proteins from the Exiguobacterium antarcticum strain B7 reveals proteins involved in adaptation to extreme environments, including high arsenic resistance. PLoS ONE 2018, 13, e0198965. [CrossRef] [PubMed]

169. Ijaq, J.; Malik, G.; Kumar, A.; Das, P.S.; Meena, N.; Bethi, N.; Sundararajan, V.S.; Suravajhala, P. A model to predict the function of hypothetical proteins through a nine-point classification scoring schema. BMC Bioinform. 2019, 20, 14. [CrossRef]

170. Naveed, M.; Tehreem, S.; Usman, M.; Chaudhry, Z.; Abbas, G. Structural and functional annotation of hypothetical proteins of human adenovirus: Prioritizing the novel drug targets. BMC Res. Notes 2017, 10, 706. [CrossRef]

171. Kim, D.W.; Lee, K.S.; Chi, Y.M. Crystal structure of hypothetical protein PA4202 from Pseudomonas aeruginosa PAO1 in complex with nitroethane as a nitroalkane substrate. Biochem. Biophys. Res. Commun. 2018, 503, 330-337. [CrossRef] 